\title{
SIKAP DAN KEPUASAN PENGGUNA SISTEM PERBENDAHARAAN DAN ANGGARAN NEGARA (SPAN)
}

Meilena Sarmilasari

Kanwil Direktorat Jenderal Perbendaharaan Provinsi Jawa Tengah

Alamat Korespondensi: lenabaskoro@gmail.com

\section{INFORMASI ARTIKEL}

Diterima Pertama

14 Juni 2016

Dinyatakan Diterima

14 September 2016

KATA KUNCI:

Integrated Financial Management Information System (IFMIS), integrated model, User Attitude, User Satisfaction, Partial Least Square (PLS).

KLASIFIKASI JEL:

030, 031, 032, 033.

\begin{abstract}
ABSTRAK
This study aims to analyze factors in the acceptance and success of the implementation of SPAN for those who have direct access to it (licensed users) at the Treasury Office (KPPN) using an integrated model. The samples are 160 licensed users in 15 KPPN in Central Java. The technical analysis used in this research is Partial Least Square (PLS) using software SmartPLS version 3.2.3. Based on the result, it was found that social factors and facilitating conditions have positive and significant effects on user attitudes. In addition, user attitudes also have positive and significant effects on user satisfaction. Meanwhile, other variables, such as performance expectations, effort expectations, information quality and systems quality, have no effect on user attitude in using SPAN.
\end{abstract}

Penelitian ini bertujuan untuk menganalisis faktor-faktor yang mempengaruhi penerimaan dan kesuksesan penerapan SPAN bagi para pengguna yang memiliki hak akses (licenced user) SPAN di KPPN dengan menggunakan model integrasi (integrated model). Pengambilan sampel menggunakan metode area sampling dengan sampel yang terdiri dari licenced user pada KPPN lingkup Jawa Tengah (15 KPPN) sebanyak 160 responden. Teknis analisis yang digunakan adalah Partial Least Square (PLS) dengan pengolahan data menggunakan perangkat lunak SmartPLS Versi 3.2.3. Berdasarkan hasil analisis, diperoleh kesimpulan bahwa pengaruh sosial dan kondisi yang memfasilitasi, berpengaruh positif dan signifikan terhadap sikap pada penggunaan. Sikap pada penggunaan juga berpengaruh positif dan signifikan terhadap kepuasan pengguna. Sedangkan variabel lain, meliputi ekspektasi kinerja, ekspektasi usaha, kualitas informasi, dan kualitas sistem tidak berpengaruh terhadap sikap pada penggunaan SPAN. 


\section{PENDAHULUAN}

\subsection{Latar Belakang}

Adanya tuntutan yang semakin besar terhadap pelaksanaan akuntabilitas publik, pada akhirnya memiliki konsekuensi pada manajemen sektor publik untuk memberikan informasi, termasuk informasi akuntansi (Mardiasmo, 2002). Dalam upaya mewujudkan akuntabilitas publik tersebut, pemerintah melakukan modernisasi anggaran dan perbendaharaan negara yang diwujudkan dalam bentuk implementasi Sistem Perbendaharaan dan Anggaran Negara (SPAN)

SPAN merupakan bagian dari Sistem Informasi Manajemen Keuangan Terintegrasi (IFMIS) yang inti utamanya adalah general ledger. Pengembangan SPAN merupakan langkah awal menuju implementasi IFMIS. Pembentukan IFMIS menjadi patokan penting bagi agenda reformasi anggaran negara karena sering dianggap sebagai prasyarat untuk mencapai manajemen penganggaran yang efektif (Diamond dan Khemani, 2005). Kimwele (2011) menyatakan bahwa yang mempengaruhi efektivitas penggunaan sistem IFMIS adalah resistensi pegawai, komitmen manajemen, kompleksitas sistem, serta kapasitas dan keterampilan pengguna.

Implementasi SPAN telah dicanangkan berdasarkan Peraturan Menteri Keuangan (PMK) No.154/PMK.05/2014 tentang Pelaksanaan SPAN. Implementasi SPAN diresmikan oleh Presiden pada tanggal 29 April 2015. Ini merupakan bentuk usaha untuk mendukung penerapan PeraturanPemerintah No. 71 tahun 2010 tentang Standar Akuntansi Pemerintah. SPAN dilaksanakan secara bertahap setelah sarana dan infrastruktur pendukung SPAN siap beroperasi. Prinsip dasar pelaksanaan SPAN antara lain dilakukan secara: 1 . Sistem elektronik dengan menggunakan aplikasi SPAN, 2. Aplikasi SPAN hanya dapat diakses oleh penerima hak akses (licenced user) yang memiliki identitas pengguna dan kata sandi, 3. Informasi elektronik, dokumen elektronik, dan/atau hasil cetak dari aplikasi SPAN merupakan alat bukti hukum yang sah, dan 4. Proses validasi dan persetujuan pada aplikasi SPAN dilakukan secara elektronik

Implementasi aplikasi SPAN dalam tahap awal tidak berjalan dengan mulus.Oleh karena itu, terdapat beberapa permasalahan yang dapat mempengaruhi sikap dan kepuasan pengguna terhadap penerimaan dan penggunaan sistem SPAN ini. McLeod (2007) menyatakan bahwa integrasi sistem informasi tidak semata mengintegrasikan komponen hardware, software, brainware, jaringan komunikasi maupun data base serta prosedur. Menurut Boodnar dan Hopwood, pengembangan Teknologi Informasi (TI) memerlukan perencanaan dan implementasi yang hati-hati untuk menghindari adanya penolakan terhadap sistem yang dikembangkan. Hal ini berhubungan dengan perubahan perilaku seseorang secara individual dalam melaksanakan pekerjaannya. ${ }^{1}$ Pengguna sistem adalah manusia yang secara psikologi memiliki suatu perilaku tertentu yang melekat pada dirinya. Dengan demikian, aspek perilaku dalam konteks manusia sebagai pengguna TI menjadi penting sebagai faktor penentu pada setiap orang yang menjalankan TI. ${ }^{2}$

Salah satu aspek penting untuk memahami pemanfaatan TI adalah dengan mengetahui faktor-faktor yang dapat mempengaruhi pemanfaatannya. Venkatesh, et al. melakukan penelitian mengenai Unified Theory of Acceptance and Use of Technology (UTAUT) yaitu dengan menggabungkan beberapa model penerimaan teknologi informasi. ${ }^{3}$ DeLone dan McLean; dan Wixom dan Todd, melakukan penelitian faktorfaktor yang mempengaruhi kesuksesan sistem informasi. ${ }^{4}$ Beberapa penelitian menggabungkan ketiga model - UTAUT, model update kesuksesan sistem, dan model Wixom dan Todd- tersebut menjadi suatu model terintegrasi (integrated model). Penelitian tersebut digunakan untuk mengukur tingkat penerimaan dan efektivitas suatu sistem informasi. Penelitian dengan model pendekatan integrasi antara lain dilakukan oleh Koh, et al., yang melakukan penelitian dengan

1 G. H Bodnar dan W. S. Hopwood, Sistem Informasi Akuntansi. Edisi Bahasa Indonesia oleh Julianto Agung Saputra dan Lilis Setiawati, Edisi 9, (Yogyakarta: Penerbit Andi, 2006).

2 F. D. Davis, "Perceived Usefulness, Perceived Ease of Use, and User Acceptance of Information Technology", MIS Quarterly, 1989, Vol. 13, No. 3, hlm. 319-339.

3 V. Venkatesh, et al., "User Acceptance of Information Technology: Toward a Unified View", MIS Quarterly, 2003, Vol. 27, No. 3, hlm. 425-447.

4 W. H. DeLone and E. R. McLean, "The DeLone and McLean Model of Information Systems Success: A Ten-Year Update", Journal of Management Information Systems, 2003, Vol. 9, No. 4, hlm. 9-3; B. H. Wixom and P. A. Todd, "A Theoretical Integration of User Satisfaction and Technology Acceptance", Information Systems Research, 2005, Vol. 16, No. 1, hlm. 85-102. 
mengusulkan model pendekatan integrasi multi level abstraksi. ${ }^{5}$

Setelah tahap implementasi, SPAN belum dievaluasi terhadap keefektivan penggunaannya. Evaluasi perlu dilakukan untuk mengetahui persepsi pengguna yang dapat mempengaruhi sikap dan kepuasan dalam menggunakan SPAN. Hal ini dimaksudkan agar SPAN dapat mencapai kesuksesan dalam penerapannya. Hasil penelitian sebelumnya yang terkait dengan SPAN masih sangat terbatas dan dilakukan sebelum tahap implementasi (misalnya Widodo, 2012; Putra, 2014); sehingga hasilnya hanya membuktikan tingkat penerimaan, tetapi belum mengukur tingkat efektivitasnya. ${ }^{6}$ Hasil penelitian yang telah dilakukan juga masih belum konsisten. Selain itu, obyek penelitian tersebut adalah seluruh pegawai yang tidak semuanya memiliki hak akses (licenced user). Hal ini berpengaruh terhadap hasil penelitian yang menggambarkan tingkat penerimaan terhadap SPAN secara umum. Sementara, penelitian ini dilakukan untuk menganalisis persepsi pengguna yang memiliki hak akses yang dapat mempengaruhi sikap dan kepuasan dalam menggunakan SPAN pada tahap awal implementasi.

Penelitian ini mengadopsi model integrasi, yaitu dengan mengintegrasikan UTAUT yang dikembangkan Venkatesh, et al. (2003); model update kesuksesan sistem dari DeLone dan McLean (2003); dan model Wixom dan Todd (2005), kemudian dimodifikasi dan disesuaikan dengan karakteristik pengguna SPAN.

\subsection{Hipotesis}

Hipotesis dalam penelitian ini adalah:

H1: Ekspektasi kinerja berpengaruh positif terhadap sikap pada penggunaan SPAN.

5 C.E. Koh, et al., "A Model for Mandatory Use of Software Technologies: An Integrative Approach by Applying Multiple Levels of Abstraction of Informing Science". Informing Science: the International Journal of an Emerging Transdiscipline, 2010, Vol.13.

6 K. Widodo, "Analisis Studi Keberterimaan Inisial Sistem Perbendaharaan dan Anggaran Negara (SPAN) Studi Pada Kantor Pelayanan Perbendaharaan Negara". Tesis, Tidak Dipublikasikan, School of Management, University of Gadjah Mada, 2012; D.H. Putra, "Analisis Faktor-faktor Yang Mempengaruhi Sikap Terhadap Penerimaan dan Penggunaan Sistem Perbendaharaan dan Anggaran Negara (SPAN) Dengan Pendekatan Technology Acceptance Model”, Jurnal Publikasi, University of Mercu Buana, 2013.
H2: Ekspektasi usaha berpengaruh positif terhadap sikap pada penggunaan SPAN.

H3: Pengaruh sosial berpengaruh positif terhadap sikap pada penggunaan SPAN.

H4: Kondisi yang memfasilitasi berpengaruh positif terhadap sikap pada penggunaan SPAN.

H5: Kualitas informasi berpengaruh positif terhadap sikap pada penggunaan SPAN.

H6: Kualitas sistem berpengaruh positif terhadap sikap pada penggunaan SPAN.

H7: Sikap pada penggunaan berpengaruh positif terhadap kepuasan pengguna SPAN.

\subsection{Rancangan Penelitian/ Research Design}

Kerangka model dalam penelitian ini merupakan integrasi dari beberapa model penerimaan sistem informasi yang pernah dilakukan pada penelitian sebelumnya. Pada dasarnya model penerimaan sistem informasi ini merupakan pengembangan dari model penerimaan TAM, yang kemudian dilakukan pengembangan oleh Venkatesh, et al. (2003) menjadi suatu model UTAUT dan model keberhasilan sistem informasi DeLone dan McLean, 2003; dan Wixom dan Todd, (2005). Untuk menguji hubungan dari masing-masing variabel, maka dalam penelitian ini dikembangkan kerangka konseptual sebagaimana Gambar 1 .

\section{Gambar 1. Kerangka Model Penelitian}

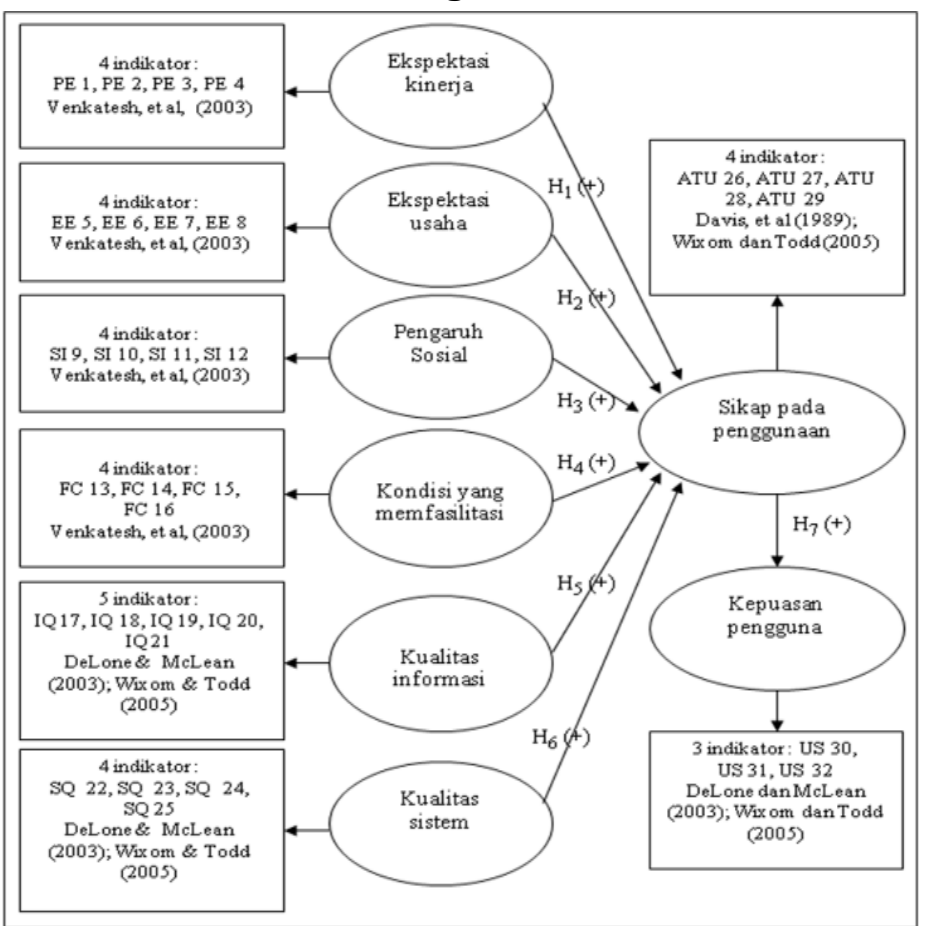




\section{KERANGKA TEORI DAN PENGEM- BANGAN HIPOTESIS}

\subsection{Kerangka Teori (Theoretical Framework)}

\subsubsection{Technology Acceptance Model (TAM)}

Teori TAM diperkenalkan oleh Fred Davis pada tahun 1986 dan merupakan hasil pengembangan dari Theory of Reasoned Action (TRA) yang lebih dahulu dikembangkan oleh Fishbein dan Ajzen pada tahun 1980. Teori TAM lebih menekankan pada persepsi kemudahan penggunaan dan kemanfaatan yang memiliki hubungan untuk memprediksi sikap dalam menggunakan sistem informasi. Menurut Davis perilaku penggunaan TI diawali oleh adanya persepsi mengenai kegunaan (usefulness) dan persepsi mengenai kemudahan menggunakan IT (ease of use). ${ }^{7}$ Persepsi terhadap manfaat TI juga mempengaruhi persepsi kemudahan penggunaan TI. Akan tetapi, hal tersebut tidak berlaku sebaliknya. Dengan demikian, selama individu merasa bahwa TI bermanfaat dalam tugas-tugasnya, ia akan berniat untuk menggunakannya terlepas apakah TI itu mudah atau tidak mudah untuk digunakan.

\subsubsection{Unified Theory of Acceptance and Use of Technology (UTAUT)}

Teori penerimaan teknologi informasi UTAUT mendasarkan pada teori-teori perilaku penggunaan teknologi dan penerimaan teknologi. Model-model penerimaan dibangun untuk menganalisis faktor yang mempengaruhi diterimanya penggunaan teknologi (user acceptance), salah satunya adalah teori gabungan penerimaan dan penggunaan teknologi atau UTAUT yang dikembangkan oleh Venkatesh, et al. pada tahun 2003. Teori ini dikembangkan melalui review dan konsolidasi dari delapan model penelitian sebelumnya seperti: Innovation Diffusion Theory/ IDT (Rogers, 1962); Theory of Reasoned Action/ TRA (Fishbein dan Azjen, 1975); Social Cognitive Theory/SCT (Bandura, 1977); Theory of Planned Behavior/ TPB (Ajzen, 1988); Technology Acceptance Model/TAM (Davis, 1989); Model of PC Utilization/ MPCU (Thompson, et al., 1991); Motivational Model/MM (Davis, et al., 1992); dan Combined TAM and TPB/ C-TAM-TPB (Taylor dan Todd, 1995). UTAUT terbukti lebih berhasil dibandingkan dengan kedelapan teori tersebut dalam menjelaskan hingga 70 persen varian pengguna (Venkatesh, et al., 2003).

7 F.D. Davis, “Technology Acceptance Model for Empirically Testing New End-User Information Systems Theory and Results", Unpublished Doctoral Dissertation, MIT, 1986.
2.1.3 Model Kesuksesaan Sistem Informasi

\subsubsection{Model Update Kesuksesan DeLone dan Mclean (1992)}

Model DeLone dan McLean (1992) merupakan salah satu model yang paling sering digunakan untuk mengukur keberhasilan sistem informasi. Tujuan utama dari model asli tersebut adalah untuk mensintesis kesuksesan sistem informasi dan membuat taksonomi komprehensif untuk mengevaluasi faktor-faktor yang mempengaruhi kesuksesan sistem informasi. Faktor-faktor tersebut adalah kualitas informasi, kualitas sistem, penggunaan, kepuasan pengguna, dampak individu, dan dampak organisasi. Mereka mengasumsikan bahwa kualitas sistem dan kualitas informasi, secara individual dan bersama-sama mempengaruhi kepuasan pengguna dan penggunaannya. Kualitas sistem dan kualitas informasi dalam penelitian ini dilihat dari persepsi pengguna. Penggunaan dan kepuasan pengguna memiliki hubungan timbal balik yang saling terkait, dan dianggap memiliki dampak langsung ke individu, yang selanjutnya dapat mempengaruhi organisasi. Dengan demikian, sistem informasi yang berkualitas akan dapat memuaskan pengguna dan mengoptimalkan kinerjanya dan organisasi sehingga pengguna akan mendukung sistem tersebut.

\subsubsection{Model Wixom dan Todd (2005)}

Wixom dan Todd (2005) mengusulkan model ketiga untuk mengukur kesuksesan sistem informasi. Mereka mengandaikan bahwa ada dua aliran yang melengkapi penelitian untuk mengukur keberhasilan sistem informasi, yaitu kepuasan pengguna dan penerimaan teknologi. Meskipun mereka mengakui bahwa kepuasan pengguna adalah prediktor lemah dari penggunaan sistem pada penerimaan teknologi, tetapi mereka menyarankan bahwa integrasi dua aliran penelitian ini akan memberikan cara yang lebih prediktif untuk mengukur penggunaan sistem. Menggunakan konseptualisasi Ajzen dan Fishbein tentang sikap berbasis obyek dibandingkan kepercayaan perilaku, mereka mengintegrasikan kedua penelitian dan menciptakan model baru untuk mengukur keberhasilan sistem informasi. ${ }^{8}$ Dalam mengintegrasikan kepuasan pengguna dan teknologi penerimaan, komponen-komponen yang termasuk dalam model mereka adalah kualitas informasi, kualitas sistem, kepuasan

8 I. Ajzen and M. Fishbein, Understanding Attitudes and Predicting Social Behaviour, Englewood Cliffs, (NJ: PrenticeHall, 1980). 
informasi, kepuasan sistem, kegunaan, kemudahan penggunaan, sikap, dan niat.

\subsection{Pengembangan Hipotesis}

2.2.1. Pengaruh ekspektasi kinerja terhadap sikap pada penggunaan SPAN

Davis (1989) dalam teori TAM menyatakan bahwa perilaku menggunakan TI diawali oleh adanya persepsi mengenai kegunaan dan persepsi mengenai kemudahan menggunakan IT. Kedua persepsi tersebut mempengaruhi sikap individu terhadap penggunaan TI. Sedangkan dalam UTAUT, Venkatesh, et al. (2003) mendefinisikan ekspektasi kinerja sebagai tingkat dimana seseorang mempercayai bahwa sistem akan membantu orang tersebut untuk memperoleh keuntungan-keuntungan kinerja pada pekerjaan. Chin dan Todd (1995) memberikan dimensi tentang kemanfaatan TI, yaitu menjadikan pekerjaan lebih mudah, bermanfaat, menambah produktivitas, mempertinggi efektivitas, dan meningkatkan kinerja pekerjaan. Davis, et al. (1989) mengidentifikasikan bahwa kemudahan pemakaian mempunyai pengaruh terhadap penggunaan teknologi informasi. Hal ini konsisten dengan penelitian Adams, et al. (1992) dan Iqbaria (1997), Thomas (2008), Koh, et al. (2010), dan Hendrawati (2013).

Berdasarkan uraian di atas, maka hipotesis yang diajukan adalah:

H1: Ekspektasi kinerja berpengaruh positif terhadap sikap pada penggunaan SPAN.

\subsubsection{Pengaruh ekspektasi usaha terhadap sikap} pada penggunaan SPAN

Dalam teori TAM yang dikembangkan oleh Davis (1989), dinyatakan bahwa persepsi terhadap manfaat TI juga mempengaruhi persepsi kemudahan penggunaan TI, tetapi tidak berlaku sebaliknya. Dengan demikian, selama individu merasa bahwa TI bermanfaat dalam tugastugasnya, ia akan berniat untuk menggunakannya terlepas apakah TI itu mudah atau tidak untuk digunakan. Pengguna teknologi informasi mempercayai bahwa teknologi informasi yang lebih fleksibel, mudah dipahami dan mudah dalam hal pengoperasiannya akan menimbulkan sikap yang baik dalam penggunaan teknologi informasi tersebut. Sedangkan dalam UTAUT, Venkatesh, et al. (2003) menyatakan ekspektasi usaha merupakan suatu tingkat kemudahan penggunaan sistem yang dapat mengurangi upaya (tenaga dan waktu) individu dalam melakukan pekerjaannya. Thompson, et al. menemukan adanya hubungan negatif antara kompleksitas dan pemanfaatan teknologi informasi. ${ }^{9}$ Sementara dalam penelitiannya, Thomas menyatakan bahwa ekspektasi usaha berpengaruh positif terhadap sikap pada penggunaan. ${ }^{10}$ Hasil penelitian juga sejalan dengan Widodo (2012) dan Hendrawati (2013). ${ }^{11}$

Berdasarkan uraian di atas, maka hipotesis yang diajukan adalah:

H2: Ekspektasi usaha berpengaruh positif terhadap sikap pada penggunaan SPAN.

2.2.3. Pengaruh variabel pengaruh sosial terhadap sikap pada penggunaan SPAN

Venkatesh, et al., (2003) dalam UTAUT menyatakan bahwa orang lain dapat menyakinkan seseorang untuk menggunakan sistem baru. Menurut Venkatesh dan Davis (2000), pengaruh sosial mempunyai dampak pada perilaku individual melalui tiga mekanisme yaitu ketaatan (compliance), internalisasi (internalization), dan identifikasi (identification). Dapat disimpulkan bahwa semakin banyak pengaruh yang diberikan sebuah lingkungan terhadap calon pengguna untuk menggunakan suatu teknologi informasi yang baru, semakin besar minat yang timbul dari personal calon pengguna tersebut. Dalam penelitiannya, Koh, et al. (2010) menyatakan bahwa kinerja seorang pengguna dalam menggunakan sistem dipengaruhi oleh kinerja pengguna lain sehingga pengguna saling terkait satu sama lain. Pengaruh sosial secara signifikan mempengaruhi sikap perilaku pengguna. Hal ini berbeda dengan penelitian Hendrawati (2013) yang menyatakan bahwa pengaruh sosial tidak memiliki pengaruh secara signifikan terhadap mental penerimaan.

9 R. L. Thompson, et al., "Personal Computing: Toward a Conceptual Model of Utilization", MIS Quarterly, 1991, Vol. 15, No. 1, hlm. 124143.

10 P. Thomas, "Information Systems Success and Technology Acceptance within a Government Organization", Dissertation, School of Buisness Computer Information System, University of North Texas, 2008.

11 K. Widodo, "Analisis Studi Keberterimaan Inisial Sistem Perbendaharaan dan Anggaran Negara (SPAN) Studi Pada Kantor Pelayanan Perbendaharaan Negara", Tesis Tidak Dipublikasikan, School of Management, University of Gadjah Mada, 2012; T. Hendrawati, 2013. "Analisis Penerimaan Sistem Informasi Integreated Library System (INLIS)", Visi Pustaka, Vol.15, No.3. 
Berdasarkan uraian di atas, maka hipotesis yang diajukan adalah:

H3: Pengaruh sosial berpengaruh positif terhadap sikap pada penggunaan SPAN.

2.2.4. Pengaruh kondisi yang memfasilitasi terhadap sikap pada penggunaan SPAN.

Venkatesh, et al., (2003) dalam UTAUT menyatakan bahwa kondisi yang memfasilitasi penggunaan teknologi informasi adalah tingkat dimana seseorang percaya bahwa infrastruktur organisasi dan teknis tersebut ada untuk mendukung penggunaan sistem. Triandis (1980) mendefinisikan kondisi pendukung sebagai faktor-faktor obyektif yang dapat mempermudah melakukan suatu tindakan. Penelitian Thompson, et al. (1991) yang mengadopsi sebagian teori yang diusulkan oleh Triandis (1980) menemukan bahwa tidak ada hubungan antara kondisi yang memfasilitasi pemakai dengan penggunaan teknologi informasi. Sementara penelitian Teo menunjukkan bahwa faktor kondisi yang memfasilitasi berpengaruh positif dan signifikan terhadap sikap pada penggunaan. ${ }^{12}$ Demikian juga dengan penelitian Hendrawati yang menyatakan bahwa kondisi yang memfasilitasi tidak memiliki pengaruh secara signifikan terhadap mental penerimaan. ${ }^{13}$

Berdasarkan uraian di atas, maka hipotesis yang diajukan adalah:

H4: Kondisi yang memfasilitasi berpengaruh positif terhadap sikap pada penggunaan SPAN.

\subsubsection{Pengaruh kualitas informasi terhadap} sikap pada penggunaan SPAN.

Wixom dan Todd (2005) dalam model kesuksesan sistem informasi menyatakan bahwa dalam hal kualitas informasi, kepercayaan berbasis obyek adalah persepsi pengguna terhadap kualitas informasi yang disertakan dalam sistem. Sepanjang segala sesuatu yang lain tetap konstan, pengguna akan puas dengan sedikit informasi jika mempunyai kualitas yang baik. Nelson, et al. (2005) menunjukkan bahwa selain kualitas output, kualitas informasi harus mempertimbangkan pengguna informasi tersebut, aplikasi yang digunakan, dan tugas yang diselesaikan. Dengan demikian, kualitas informasi

12 T. Teo, "Modelling the Influences of Beliefs on Pre-Service Teachers' Attitudes towards Computer Use", European Journal of Educational Research, 2012, Vol. 1, No.1.

13

T. Hendrawati, "Analisis Penerimaan Sistem Informasi Integreated Library System (INLIS)", Visi Pustaka, 2013, Vol.15, No.3. adalah sejauh mana informasi membantu pengguna dalam menyelesaikan tugas yang diberikan. Kualitas informasi terdiri dari empat dimensi: akurasi, kelengkapan, berlaku saat ini, dan format. Dalam penelitiannya, Hendrawati (2013) menyatakan bahwa mental penerimaan pegawai dipengaruhi oleh kualitas informasi yang dapat mempengaruhi tingkat kepuasan pegawai terhadap perolehan informasi.

Berdasarkan uraian di atas, maka hipotesis yang diajukan adalah:

H5: Kualitas informasi berpengaruh positif terhadap sikap pada penggunaan SPAN.

\subsubsection{Pengaruh kualitas sistem terhadap sikap pada penggunaan SPAN.}

DeLone dan McLean (1992) dalam model kesuksesan sistem informasi menyatakan bahwa kualitas sistem mengacu pada kualitas kinerja sistem tersebut. Kualitas sistem memiliki efek langsung pada penggunaan dan kepuasan pengguna. Nelson, et al. mengandaikan bahwa meskipun kemudahan penggunaan dan kualitas sistem serupa, kemudahan penggunaan mungkin merupakan anteseden kualitas sistem. Kualitas sistem terdiri dari lima dimensi utama yang meliputi fleksibilitas, kehandalan, waktu respon, aksesibilitas, dan integrasi. ${ }^{14}$

Berdasarkan uraian di atas, maka hipotesis yang diajukan adalah:

H6: Kualitas sistem berpengaruh positif terhadap sikap pada penggunaan SPAN.

\subsubsection{Pengaruh sikap pada penggunaan berpengaruh terhadap kepuasan pengguna SPAN.}

DeLone dan McLean (1992) dalam model kesuksesan sistem informasi menyatakan bahwa sikap pengguna terhadap penggunaan sistem dikaitkan dengan kepuasan pengguna. Menurut Venkatesh, et al. (2003) sikap terhadap penggunaan didefinisikan sebagai reaksi keseluruhan afektif individu untuk menggunakan sistem. Melone (1990) juga mendefinisikan bahwa sikap pengguna dalam sistem informasi sebagai kecenderungan untuk merespon positif atau tidak, baik ke sistem komputer, aplikasi, anggota staf sistem, atau proses yang berkaitan dengan penggunaan sistem aplikasi. Doll dan Torkzadeh (1988) mendefinisikan kepuasan

${ }^{14}$ R. Nelson, et al., 2005. "Antecedents of Information and System Quality: An Empirical Examination within the Context of Data Warehousing", Journal of Management Information Systems, Vol. 21, No. 4, hlm. 199235. 
pengguna sebagai sikap afektif terhadap aplikasi komputer tertentu oleh seseorang yang berinteraksi dengan aplikasi secara langsung. Studi empiris telah memberikan dukungan yang konsisten dan positif terhadap hubungan yang signifikan antara sikap dan kepuasan pengguna (misalnya, Koh, et al. 2010; Igbaria dan Nachman, 1990). Dalam penelitiannya Teo (2010) menemukan bahwa kompleksitas teknologi memiliki pengaruh langsung dan signifikan terhadap sikap penggunaan teknologi.

Berdasarkan uraian di atas, maka hipotesis yang diajukan adalah:

H7: Sikap pada penggunaan berpengaruh positif terhadap kepuasan pengguna SPAN.

\section{METODOLOGI PENELITIAN}

\subsection{Desain Penelitian}

Penelitian ini adalah penelitian kausal (causal research), yang menjelaskan hubungan kausal dan korelasional antar variabel melalui pengujian hipotesis. Sedangkan pendekatan dalam penelitian ini menggunakan pendekatan analisis kuantitatif. Penelitian ini menggunakan data primer dan data sekunder. Data primer berupa data cross-section yang diperoleh dari para responden dengan menggunakan kuesioner yang terdiri dari butir-butir pernyataan yang sifatnya tertutup. Data sekunder diperoleh dari mempelajari laporan Komite Implementasi SPAN SAKTI (KISS), jurnal-jurnal penelitian terdahulu, buku teks, majalah-majalah yang menunjang pembahasan dan analisis penelitian lapangan.

\subsection{Populasi dan Sampling Penelitian}

Populasi penelitian ini adalah licenced user SPAN pada KPPN seluruh Indonesia. Metode penarikan sampel yang digunakan adalah area sampling method, yaitu teknik sampling yang sangat cocok ketika tujuan dari penelitian ini terbatas untuk wilayah atau daerah tertentu. ${ }^{15}$ Sampel populasi adalah licenced user pada KPPN lingkup Jawa Tengah. Jumlah sampel sebanyak 160 responden, dengan rincian sebaran sampel masing-masing KPPN, sebagaimana Tabel 1.

15 U. Sekaran and R. Bougie, Research Methods for Business: A Skill Building Approach. Fifth Edition. (United Kingdom: John Wiley \& Sons, 2010), hlm. 304.
Tabel 1. Rincian Sebaran Sampel

\begin{tabular}{|rlccc} 
N0 & OBYEK PENELITIAN & TIPE KPPN & KATEGORI & JML \\
\hline 1 & KPPN SemarangI & $\mathrm{A} 1$ & $\mathrm{M}$ & 12 \\
\hline 2 & KPPN SemarangII & $\mathrm{A} 1$ & $\mathrm{M}$ & 12 \\
\hline 3 & KPPN Kudus & $\mathrm{A} 1$ & $\mathrm{M}$ & 12 \\
\hline 4 & KPPN Pati & $\mathrm{A} 1$ & $\mathrm{M}$ & 12 \\
\hline 5 & KPPN Purwodadi & $\mathrm{A} 2$ & $\mathrm{~S}$ & 8 \\
\hline 6 & KPPN Surakarta & $\mathrm{A} 1$ & $\mathrm{M}$ & 12 \\
\hline 7 & KPPN Sragen & $\mathrm{A} 2$ & $\mathrm{~S}$ & 12 \\
\hline 8 & KPPN Klaten & $\mathrm{A} 1$ & $\mathrm{M}$ & 12 \\
\hline 9 & KPPN Magelang & $\mathrm{A} 1$ & $\mathrm{M}$ & 12 \\
\hline 10 & KPPN Purworejo & $\mathrm{A} 2$ & $\mathrm{~S}$ & 8 \\
\hline 11 & KPPN Banjamegara & $\mathrm{A} 2$ & $\mathrm{~S}$ & 8 \\
\hline 12 & KPPN Purwokerto & $\mathrm{A} 1$ & $\mathrm{M}$ & 12 \\
\hline 13 & KPPN Cilacap & $\mathrm{A} 2$ & $\mathrm{~S}$ & 8 \\
\hline 14 & KPPN Pekalongan & $\mathrm{A} 1$ & $\mathrm{M}$ & 12 \\
\hline 15 & KPPN Tegal & $\mathrm{A} 1$ & $\mathrm{M}$ & 12 \\
\hline & & Total Populasi & & 160 \\
\hline
\end{tabular}

Sumber: Direktorat Transformasi Perbendaharaan (2015)

\subsection{Variabel Penelitian dan Definisi Operasional Variabel}

Penelitian ini menggunakan delapan variabel laten, yaitu:

1) Ekspektasi kinerja, ekspektasi usaha, pengaruh sosial, kondisi yang memfasilitasi, kualitas informasi dan kualitas sistem yang merupakan variabel eksogen (variabel independen);

2) Sikap pada penggunaan dan kepuasan pengguna yang merupakan variabel endogen (variabel dependen)

Dalam penelitian ini, semua variabel laten diukur dengan beberapa indikator secara reflektif. Teknik pengukuran yang digunakan untuk mengubah data kualitatif dari kuesioner menjadi suatu data kuantitatif adalah Summated Rating Method: The Likert Scale, yaitu menggunakan skala 5 poin dengan pilihan jawaban: "1= Sangat Tidak Setuju", "2= Tidak Setuju", "3= Netral", "4= Setuju", dan " $5=$ Sangat Setuju".

\subsection{Metode Pengumpulan Data}

Kuesioner dikirim ke KPPN lingkup Jawa Tengah dengan diantar langsung untuk KPPN yang berada di Kota Semarang. Bagi KPPN yang berada di luar Kota Semarang, kuesioner dikirim melalui pos yang ditujukan kepada Duta SPAN Unit (DSU). Responden mengisi secara langsung kuesioner yang telah disediakan (dalam bentuk hard copy). Kuesioner yang telah diisi dikumpulkan dan dikirim kembali oleh DSU melalui pos untuk KPPN di luar Kota Semarang, dan diambil secara langsung untuk KPPN yang berada di Kota Semarang. Kuesioner dikirim secara serentak pada tanggal 26 Oktober 2015. 
Batas waktu (cut off) yang diberikan untuk pengisian dan pengembalian kuesioner adalah sampai dengan tanggal 6 Nopember 2015.

\subsection{Uji Non-Respon Bias}

Uji non-respon bias dilakukan dengan cara membandingkan karakteristik responden yang berpartisipasi dengan responden yang tidak berpartisipasi. Pengujian dilakukan dengan alat analisis uji beda $t$-test. Uji beda $t$-test dilakukan dengan cara membandingkan perbedaan antara dua nilai rata-rata dengan standar error dari perbedaan rata-rata dua sampel. Jadi tujuan uji beda $t$-test adalah membandingkan rata-rata dua grup yang tidak berhubungan satu dengan yang lain. Apakah kedua grup tersebut mempunyai nilai rata-rata yang sama ataukah sama secara signifikan. ${ }^{16}$ Pengujian non-respon bias dilakukan dengan menggunakan program SPSS versi 23.

\subsection{Teknik Analisis}

\subsubsection{Statistik Deskriptif}

Statistik deskriptif menjelaskan berbagai karakteristik data seperti rata-rata (mean), jumlah (sum), simpangan baku (standard deviation), varians (variance), rentang (range), nilai minimum dan maksimum, kurtosis dan kemencengan distribusi (skewness).

\subsubsection{Structural Equation Modeling (SEM)}

Teknis analisis data dalam penelitian ini menggunakan SEM dengan alat analisis PLS. Perangkat lunak yang digunakan adalah SmartPLS versi 3.2.3. Tahapan-tahapan dalam pengujian model empiris dengan perangkat lunak SmartPLS adalah sebagai berikut:

1) Evaluasi Model Pengukuran (Outer Model)

Evaluasi model pengukuran dilakukan untuk menilai validitas dan reliabilitas dari indikator-indikator pembentuk variabel laten.

2) Model Strukural (Inner Model)

Model struktural menggambarkan hubungan antara konstruk dan konstruk lainnya. Model struktural dievaluasi dengan menggunakan R-Square untuk konstruk dependen, Stone-Geisser $\mathrm{Q}^{2}$ test untuk predictive relevance dan uji $\mathrm{t}$, serta signifikansi dari koefisien parameter jalur struktural (Ghozali, 2011).
3) Pengujian Hipotesis

Dalam pengujian hipotesis ini dasar untuk mengetahui signifikansi hubungan antara variabel laten eksogen dan endogen adalah dengan melihat besaran nilai $t$-statistic dan $p$ value.

\section{HASIL PENELITIAN DAN PEMBAHASAN}

\subsection{Data Penelitian}

\subsubsection{Data Deskriptif Responden}

Responden dalam penelitian ini adalah licenced user SPAN yang berada di KPPN lingkup Jawa Tengah (15 KPPN) sebanyak 160 orang. Tingkat pengembalian kuesioner sebanyak 157 responden atau mencapai $98,13 \%$, dengan rincian sebagaimana Tabel 2 .

\section{Tabel 2. Tingkat Pengembalian Kuesioner}

\begin{tabular}{|c|c|c|c|c|c|}
\hline $\begin{array}{l}N \\
0\end{array}$ & OBYEK PENELITIAN & DIKIRMM & KEMBALI & $\%$ & KET. \\
\hline 1 & KPPNSemarangI & 12 & 12 & 100 & sebelum cut off \\
\hline 2 & KPPNSemarangII & 12 & 12 & 100 & sebelum cut off \\
\hline 3 & KPPNKudus & 12 & 10 & 83,33 & sebelum cut off \\
\hline 4 & KPPNPati & 12 & 12 & 100 & sebelum cut off \\
\hline 5 & KPPNPurwodadi & 8 & 8 & 100 & sebelum cut off \\
\hline 6 & KPPN Surakarta & 12 & 12 & 100 & setelah cut off \\
\hline 7 & KPPNSragen & 8 & 8 & 100 & setelah cut off \\
\hline 8 & KPPN Klaten & 12 & 12 & 100 & sebelum cut off \\
\hline 9 & KPPNMagalang & 12 & 12 & 100 & setelah cut off \\
\hline 10 & KPPNPurworejo & 8 & 8 & 100 & sebelum cut off \\
\hline 11 & KPPNBanjarnegara & 8 & 8 & 100 & sebelum cut off \\
\hline 12 & KPPNPurwokerto & 12 & 11 & 91,67 & setelah cut off \\
\hline 13 & KPPNCilacap & 8 & 8 & 100 & setelah cut off \\
\hline 14 & KPPNPekalongan & 12 & 12 & 100 & sebelum cut off \\
\hline 15 & KPPN Tegal & 12 & 12 & 100 & sebelum cut off \\
\hline & Jumlah & 160 & 157 & $98,13 \%$ & \\
\hline
\end{tabular}

Sumber : Data primer, diolah.

Karakteristik responden hasil pengumpulan data meliputi jenis kelamin, pendidikan, jabatan/ posisi licenced user, usia, dan pelatihan terkait SPAN yang pernah diikuti.

\subsubsection{Statistik Deskriptif Variabel Penelitian}

Statistik deskriptif semua variabel menunjukkan nilai kisaran dan rata-rata aktual lebih tinggi dibanding nilai kisaran dan rata-rata teoritis, sebagaimana terlihat pada Tabel 3.

16 I.Ghozali, Aplikasi Analisis Multivariate dengan Program IBM SPSS 19, Edisi 5, (Semarang: Badan Penerbit Undip, 2011). 


\section{Tabel 3. Statistik Deskriptif Variabel Penelitian}

\begin{tabular}{|c|c|c|c|c|c|c|}
\hline \multirow{2}{*}{ Variabel } & \multirow{2}{*}{$\begin{array}{l}\text { Jumlah } \\
\text { Indikator }\end{array}$} & \multicolumn{2}{|c|}{ Teoritis } & \multicolumn{2}{|c|}{ Aktual } & \multirow{2}{*}{$\begin{array}{l}\text { Standar } \\
\text { Deriasi }\end{array}$} \\
\hline & & Kisaran & Mean & Kisaran & Mean & \\
\hline Ekspektasi Kinerja & 4 & $4 \cdot 20$ & 12.00 & $8 \cdot 20$ & 16.84 & 2.31 \\
\hline Ekspeltasi Usahs & 4 & $4 \cdot 20$ & 12.00 & $10 \cdot 20$ & 16.52 & 2.01 \\
\hline Pengaruh Sosial & 4 & $4 \cdot 20$ & 12.00 & 9.20 & 17.34 & 1.95 \\
\hline $\begin{array}{l}\text { Kondisi Yang } \\
\text { Memfasilitasi }\end{array}$ & 4 & $4 \cdot 20$ & 12.00 & 8.20 & 15.92 & 2.10 \\
\hline Kualitas Informasi & 5 & 5.25 & 15.00 & 10.25 & 20.91 & 2.51 \\
\hline Kualitas Sistem & 4 & $4 \cdot 20$ & 12.00 & $11 \cdot 20$ & 16.71 & 1.99 \\
\hline Sikap Pada Penggunam & 4 & $4 \cdot 20$ & 12.00 & $9 \cdot 20$ & 17.13 & 2.25 \\
\hline Kepuasan Pengguna & 3 & $3 \cdot 15$ & 9.00 & $6 \cdot 15$ & 12.42 & 1.67 \\
\hline
\end{tabular}

Sumber : Output SPSS, diolah.

\subsection{Pengujian dan Analisis Data}

\subsubsection{Uji Non-Response Bias}

Uji non-response bias dalam penelitian ini dilakukan dengan cara membandingkan jawaban responden yang datang sebelum batas waktu pengembalian (cut off) sebagai wakil dari responden yang benar-benar ingin berpartisipasi dengan rata-rata jawaban responden yang datang setelah cut off sebagai sebagai wakil dari responden yang tidak berpartisipasi. Tahapantahapan dalam analisis hasil uji beda t-test menurut Ghozali (2011) adalah sebagai berikut:

1) Analisis Output Bagian Pertama (Group Statistics)

Analisis dilakukan dengan cara membandingkan rata-rata antara kedua grup, apakah terjadi perbedaan atau tidak. Hasil pengujian diperoleh bahwa rata-rata jawaban responden yang datang sebelum dan setelah cut off berbeda, namun tidak terlalu signifikan. Output group statistics dapat dilihat sebagaimana pada Tabel4.

Tabel 4. Group Statistics

\begin{tabular}{|c|c|c|c|c|c|}
\hline Variabel & Group & $\mathrm{N}$ & Mean & $\begin{array}{c}\text { Std. } \\
\text { Deviation }\end{array}$ & $\begin{array}{c}\text { Std. Error } \\
\text { Mean }\end{array}$ \\
\hline \multirow[t]{2}{*}{ Ekspektasi Kinerja } & Sebelum cut off & 106 & 16.67 & 2.45 & 0.24 \\
\hline & Setelah cut off & 51 & 17.20 & 1.97 & 0.28 \\
\hline \multirow[t]{2}{*}{ Ekspektasi Usahs } & Sebelum cut off & 106 & 16.55 & 2.20 & 0.21 \\
\hline & Setelah cut off & 51 & 16.47 & 1.57 & 0.22 \\
\hline \multirow[t]{2}{*}{ Pengaruh Sosial } & Sebelum cut off & 106 & 17.12 & 2.02 & 0.20 \\
\hline & Setelah cut off & 51 & 17.78 & 1.72 & 0.24 \\
\hline \multirow[t]{2}{*}{ Kondisi YangMemfas litasi } & Sebelum cut off & 106 & 15.71 & 2.22 & 0.22 \\
\hline & Setelah cut off & 51 & 16.35 & 1.76 & 0.25 \\
\hline \multirow[t]{2}{*}{ Kualitas Informasi } & Sebelum cut off & 106 & 20.81 & 2.61 & 0.25 \\
\hline & Setelah cut off & 51 & 21.12 & 2.30 & 0.32 \\
\hline \multirow[t]{2}{*}{ Kualitas Sistem } & Sobelum cut off & 105 & 16.67 & 2.06 & 0.20 \\
\hline & Setelah cut off & 51 & 16.86 & 1.87 & 0.26 \\
\hline \multirow[t]{2}{*}{ Sikap Pada Penggunaan } & Sebelum cut off & 106 & 17.00 & 2.37 & 0.23 \\
\hline & Setelah cut off & 51 & 17.41 & 1.98 & 0.28 \\
\hline \multirow[t]{2}{*}{ Kepuasan Pengguna } & Sebelum cut off & 106 & 12.34 & 1.76 & 0.17 \\
\hline & Setelah cut off & 51 & 12.59 & 1.46 & 0.20 \\
\hline
\end{tabular}

Sumber : Output SPSS, diolah.
2) Analisis Output Bagian Kedua (Independent Sample Test)

Hasil pengujian levene's test diperoleh nilai probabilitas semua variabel $>0.05$. Dengan demikian dapat disimpulkan bahwa variance populasi antara jawaban responden yang datang sebelum dan setelah cut off adalah sama, dan uji beda t-test harus menggunakan equal variance assumed. Nilai probabilitas signifikansi semua variabel lebih besar 0.000 (two tail), sehingga dapat disimpulkan bahwa rata-rata jawaban responden yang datang sebelum dan setelah cut off tidak berbeda secara signifikan. Oleh karena itu, penelitian ini dapat dikatakan telah memenuhi syarat representasi populasi. Output independent sample test tersaji pada Tabel 5.

Tabel 5.Independent Sample Test

\begin{tabular}{|c|c|c|c|c|c|c|c|c|}
\hline & \multicolumn{2}{|c|}{$\begin{array}{l}\text { Levene's } \\
\text { Test for } \\
\text { Equality of } \\
\text { Variances }\end{array}$} & \multicolumn{5}{|c|}{ t-test for Equality of Means } \\
\hline & & F & Sig. & $t$ & df & \begin{tabular}{c|} 
Sig. \\
(2. \\
tailed) \\
\end{tabular} & $\begin{array}{c}\text { Mean } \\
\text { Difference }\end{array}$ & $\begin{array}{l}\text { Std. Error } \\
\text { Difference }\end{array}$ \\
\hline \multirow[t]{2}{*}{$\begin{array}{l}\text { Ekspelktasi } \\
\text { Kinerja }\end{array}$} & $\begin{array}{l}\text { Equal variances } \\
\text { assumed }\end{array}$ & 1.133 & .289 & -1.340 & 155 & .182 & -.52627 & .39280 \\
\hline & $\begin{array}{l}\text { Equal variances } \\
\text { not assumed }\end{array}$ & & & -1.445 & 120.297 & .151 & -.52627 & .36421 \\
\hline \multirow[t]{2}{*}{$\begin{array}{l}\text { Ekspelktasi } \\
\text { Usaha }\end{array}$} & $\begin{array}{l}\text { Equal variances } \\
\text { assumed }\end{array}$ & 4.788 & .030 & .223 & 155 & .824 & .07658 & .34384 \\
\hline & $\begin{array}{l}\text { Equal variances } \\
\text { not as sumed }\end{array}$ & & & .250 & 132.925 & .803 & .07658 & .30625 \\
\hline \multirow[t]{2}{*}{$\begin{array}{l}\text { Pengaruh } \\
\text { Sosial }\end{array}$} & $\begin{array}{l}\text { Equal variances } \\
\text { assumed }\end{array}$ & .437 & .509 & -2.014 & 155 & .046 & -.66167 & .32853 \\
\hline & $\begin{array}{l}\text { Equal variances } \\
\text { not assumed }\end{array}$ & & & -2.128 & 114.020 & .035 & -.66167 & .31094 \\
\hline \multirow[t]{2}{*}{$\begin{array}{l}\text { Kondisi Yang } \\
\text { Momfasilitasi }\end{array}$} & $\begin{array}{l}\text { Equal variances } \\
\text { assumed }\end{array}$ & 1.007 & .317 & -1.819 & 155 & .071 & 4539 & .35473 \\
\hline & $\begin{array}{l}\text { Equal variances } \\
\text { not assumed }\end{array}$ & & & -1.969 & 121.432 & .051 & -.64539 & .32771 \\
\hline \multirow[t]{2}{*}{$\begin{array}{l}\text { Kualitas } \\
\text { Informasi }\end{array}$} & $\begin{array}{l}\text { Equal variances } \\
\text { assumed }\end{array}$ & .153 & .696 & -.714 & 155 & .476 & -.30633 & .42884 \\
\hline & $\begin{array}{l}\text { Equal variances } \\
\text { not assumed }\end{array}$ & & &,- 746 & 110.798 & .457 & -.30633 & .41035 \\
\hline \multirow[t]{2}{*}{$\begin{array}{l}\text { Kualitas } \\
\text { Sistem }\end{array}$} & $\begin{array}{l}\text { Equal variances } \\
\text { assumed }\end{array}$ & .213 & .645 & -.576 & 154 & .566 & -.19608 & .34063 \\
\hline & $\begin{array}{l}\text { Equal variances } \\
\text { not assumed }\end{array}$ & & & -.595 & 108.239 & .553 & -.19608 & .32937 \\
\hline \multirow[t]{2}{*}{$\begin{array}{l}\text { Slikap Pada } \\
\text { Penggunasn }\end{array}$} & $\begin{array}{l}\text { Equal variances } \\
\text { assumed }\end{array}$ & .532 & .467 & -1.073 & 155 & .285 & -.41176 & .38384 \\
\hline & $\begin{array}{l}\text { Equal variances } \\
\text { not as sumed }\end{array}$ & & & -1.142 & 116.294 & .256 & -.41176 & .36057 \\
\hline \multirow[t]{2}{*}{$\begin{array}{l}\text { Kepuasan } \\
\text { Pengguna }\end{array}$} & $\begin{array}{l}\text { Equalvariances } \\
\text { assumed }\end{array}$ & .805 & .371 & -.874 & 155 & .384 & -.24861 & .28455 \\
\hline & $\begin{array}{l}\text { Equal variances } \\
\text { not assumed }\end{array}$ & & & -.933 & 117.296 & .353 & -.24861 & .26641 \\
\hline
\end{tabular}

Sumber: Output SPSS, diolah

\subsubsection{Pengujian Model Pengukuran}

Terdapat tiga kriteria untuk menilai model pengukuran, yaitu validitas konvergen, validitas diskriminan dan composite reliability.

1) Uji Validitas Konvergen

Rule of thumb yang digunakan untuk menilai validitas konvergen adalah nilai loading factor yang harus lebih dari 0.7 untuk penelitian yang bersifat confirmatory. Sedangkan nilai loading factor antara 0.5 - 0.6 untuk penelitian yang bersifat exploratory masih dapat diterima, serta nilai AVE harus lebih besar dari 0.5. Namun 
demikian, untuk penelitian tahap awal dari pengembangan skala pengukuran, nilai loading factor 0.5 - 0.6 masih dianggap cukup (Chin 1998 dalam Ghozali dan Latan, 2015). Hasil uji validitas konvergen menunjukkan nilai loading factor lebih besar dari 0.7, sehingga seluruh indikator yang digunakan sudah memenuhi validitas konvergen. Dengan demikian indikator-indikator tersebut selanjutnya dapat digunakan untuk pengolahan data. Nilai loading factor terlihat pada Gambar 2.

\section{Gambar 2. Nilai Loading Factor}

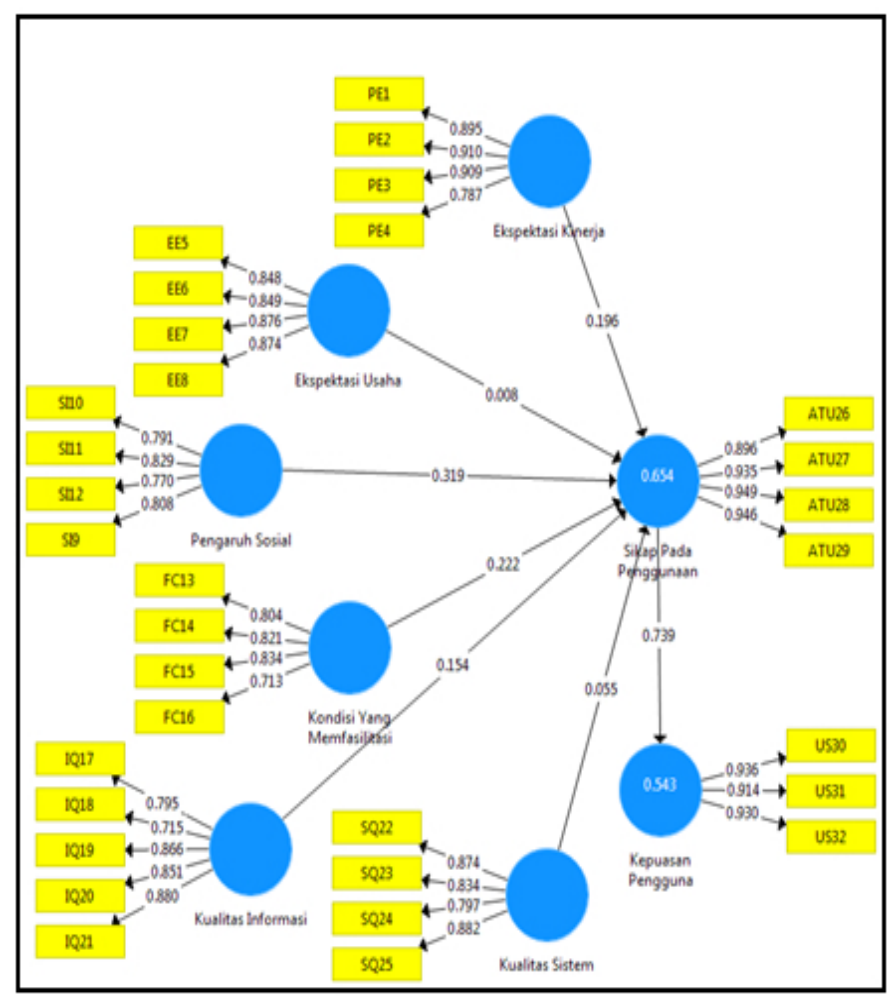

Sumber: Output SmartPLS 3.2.3.

Cara lain yang digunakan untuk melihat validitas konvergen adalah melalui nilai AVE yang direkomendasikan yaitu harus lebih besar dari 0.5 . Ini berarti bahwa $50 \%$ atau lebih variance dari indikator dapat dijelaskan (Ghozali, 2014). Sebagaimana terlihat pada Tabel 6, hasil uji menunjukkan nilai AVE semua konstruk lebih besar dari 0.5 sehingga memenuhi persyaratan validitas konvergen.
Tabel 6. Nilai AVE

\begin{tabular}{|l|l|}
\hline \multicolumn{1}{|c|}{ VARIABEL } & AVE \\
\hline Ekspektasi Kinerja & 0.768 \\
\hline EkspektasiUsaha & 0.743 \\
\hline Pengaruh Sosial & 0.859 \\
\hline Kondisi Yang Memfasilitasi & 0.631 \\
\hline Kualitas Informasi & 0.678 \\
\hline Kualitas Sistem & 0.718 \\
\hline Sikap Pada Penggunaan & 0.640 \\
\hline Kepuasan Pengguna & 0.869 \\
\hline
\end{tabular}

Sumber: Output SmartPLS 3.2.3.

2) Uji Validitas Diskriminan

Validitas diskriminan dari model pengukuran dengan indikator reflektif dinilai berdasarkan cross loading pengukuran dengan konstruk. Jika korelasi konstruk dengan item pengukuran lebih besar daripada ukuran konstruk lainnya, maka hal ini menunjukkan bahwa konstruk laten memprediksi ukuran pada blok mereka lebih baik daripada ukuran pada blok lainnya. ${ }^{17}$ Cara untuk menguji validitas diskriminan dengan indikator reflektif yaitu dengan melihat nilai cross loading untuk setiap variabel harus lebih besar 0.7.18 Nilai cross loading sebagaimana terlihat pada Tabel 7.

17 I. Ghozali, Partial Least Squares: Konsep, Metode dan Aplikasi Menggunakan WarpPLS 4.0, Edisi 2, (Semarang: Badan Penerbit Undip, 2014).

18 I. Ghozali dan H. Latan, Partial Least Squares: Konsep, Metode dan Aplikasi Menggunakan Program SmartPLS 3.2.1 Untuk Penelitian Empiris, Edisi 2, (Semarang: Badan Penerbit Undip, 2015). 


\section{Tabel 7. Nilai Cross Loading}

\begin{tabular}{|c|c|c|c|c|c|c|c|c|}
\hline Indikator & $\begin{array}{l}\text { Ekspelkta } \\
\text { si Kinerja }\end{array}$ & $\begin{array}{c}\text { Ekspelta } \\
\text { si Usaha }\end{array}$ & $\begin{array}{l}\text { Pengaruh } \\
\text { Sosial }\end{array}$ & $\begin{array}{c}\text { Kondisi } \\
\text { Yang } \\
\text { Memfasili } \\
\text { tasi }\end{array}$ & $\begin{array}{c}\text { Kualitas } \\
\text { Informasi }\end{array}$ & $\begin{array}{c}\text { Kualitas } \\
\text { Sistem }\end{array}$ & $\begin{array}{l}\text { Sikap Pada } \\
\text { Pengguanan }\end{array}$ & $\begin{array}{l}\text { Kepuass } \\
\text { Penggur }\end{array}$ \\
\hline PE1 & 0.895 & 0.534 & 0.611 & 0.522 & 0.540 & 0.654 & 0.588 & 0.606 \\
\hline PE2 & 0.910 & 0.523 & 0.622 & 0.544 & 0.565 & 0.529 & 0.616 & 0.603 \\
\hline PE3 & 0.909 & 0.628 & 0.591 & 0.527 & 0.577 & 0.603 & 0.644 & 0.587 \\
\hline PE4 & 0.787 & 0.649 & 0.513 & 0.550 & 0.499 & 0.448 & 0.532 & 0.541 \\
\hline EE5 & 0.464 & 0.848 & 0.424 & 0.419 & 0.499 & 0.451 & 0.399 & 0.556 \\
\hline EE6 & 0.544 & 0.849 & 0.481 & 0.417 & 0.497 & 0.474 & 0.448 & 0.475 \\
\hline EE7 & 0.663 & 0.876 & 0.595 & 0.504 & 0.564 & 0.593 & 0.586 & 0.556 \\
\hline EE8 & 0.577 & 0.874 & 0.529 & 0.452 & 0.581 & 0.556 & 0.512 & 0.578 \\
\hline SI9 & 0.571 & 0.421 & 0.808 & 0.615 & 0.587 & 0.535 & 0.680 & 0.600 \\
\hline SII0 & 0.497 & 0.537 & 0.791 & 0.474 & 0.549 & 0.540 & 0.529 & 0.541 \\
\hline SI11 & 0.579 & 0.535 & 0.829 & 0.508 & 0.521 & 0.550 & 0.567 & 0.579 \\
\hline SI12 & 0.480 & 0.435 & 0.770 & 0.381 & 0.449 & 0.439 & 0.542 & 0.424 \\
\hline $\mathrm{FC} 13$ & 0.518 & 0.435 & 0.602 & 0.804 & 0.538 & 0.526 & 0.594 & 0.545 \\
\hline $\mathrm{FCl} 14$ & 0.494 & 0.452 & 0.542 & 0.821 & 0.607 & 0.591 & 0.587 & 0.612 \\
\hline $\mathrm{FC} 15$ & 0.493 & 0.409 & 0.454 & 0.834 & 0.581 & 0.621 & 0.565 & 0.603 \\
\hline $\mathrm{FC} 16$ & 0.424 & 0.362 & 0.361 & 0.713 & 0.416 & 0.485 & 0.418 & 0.450 \\
\hline IQ17 & 0.464 & 0.481 & 0.547 & 0.603 & 0.795 & 0.623 & 0.514 & 0.581 \\
\hline IQ18 & 0.409 & 0.399 & 0.437 & 0.505 & 0.715 & 0.524 & 0.537 & 0.559 \\
\hline IQ19 & 0.567 & 0.582 & 0.560 & 0.588 & 0.866 & 0.703 & 0.571 & 0.691 \\
\hline IQ20 & 0.560 & 0.558 & 0.540 & 0.537 & 0.851 & 0.681 & 0.577 & 0.693 \\
\hline IQ21 & 0.552 & 0.544 & 0.630 & 0.576 & 0.880 & 0.690 & 0.620 & 0.659 \\
\hline SQ22 & 0.504 & 0.478 & 0.539 & 0.596 & 0.660 & 0.874 & 0.546 & 0.663 \\
\hline $\mathrm{SQ} 23$ & 0.581 & 0.579 & 0.541 & 0.541 & 0.624 & 0.834 & 0.551 & 0.635 \\
\hline SQ24 & 0.464 & 0.414 & 0.471 & 0.661 & 0.583 & 0.797 & 0.509 & 0.633 \\
\hline SQ25 & 0.606 & 0.582 & 0.625 & 0.591 & 0.772 & 0.882 & 0.645 & 0.792 \\
\hline ATU26 & 0.576 & 0.488 & 0.672 & 0.617 & 0.545 & 0.585 & 0.896 & 0.648 \\
\hline ATU27 & 0.676 & 0.561 & 0.682 & 0.646 & 0.639 & 0.628 & 0.935 & 0.683 \\
\hline ATU28 & 0.642 & 0.548 & 0.681 & 0.671 & 0.688 & 0.640 & 0.949 & 0.693 \\
\hline ATU29 & 0.641 & 0.544 & 0.692 & 0.637 & 0.682 & 0.636 & 0.946 & 0.729 \\
\hline US30 & 0.688 & 0.617 & 0.640 & 0.662 & 0.764 & 0.753 & 0.673 & 0.936 \\
\hline US31 & 0.577 & 0.554 & 0.566 & 0.632 & 0.704 & 0.751 & 0.653 & 0.914 \\
\hline US32 & 0.590 & 0.578 & 0.666 & 0.655 & 0.690 & 0.745 & 0.726 & 0.930 \\
\hline
\end{tabular}

Sumber: Output SmartPLS 3.2.3.

Dari Tabel 7 terlihat bahwa korelasi konstruk ekspektasi kinerja dengan indikatornya adalah lebih tinggi jika dibandingkan dengan korelasi indikator ekspektasi kinerja dengan konstruk lainnya. Hal ini juga berlaku sebaliknya yaitu korelasi konstruk lainnya dengan indikatornya lebih tinggi dibandingkan dengan korelasi antara indikator konstruk lainnya dengan konstruk ekspektasi kinerja. Hal ini menunjukkan bahwa semua konstruk memprediksi indikator pada blok mereka lebih baik dibandingkan dengan indikator blok lainnya, sehingga dapat dikatakan memenuhi persyaratan validitas diskriminan.

Cara lain yang dapat digunakan untuk menguji validitas diskriminan yaitu dengan membandingkan nilai akar kuadrat AVE untuk setiap konstruk dengan korelasi antara konstruk dengan konstruk lainnya dalam model. Jika nilai akar kuadrat AVE setiap konstruk lebih besar dari nilai korelasi antara konstruk dengan konstruk lainnya dalam model, maka dikatakan validitas diskriminan memiliki nilai yang baik. Nilai AVE direkomendasikan harus lebih besar dari 0.5 yang berarti bahwa $50 \%$ atau lebih variance dari indikator dapat dijelaskan (Fornel dan Larcker, 1981 dalam Ghozali 2014). Nilai kuadrat AVE pada output validitas diskriminan tersaji pada
Tabel 8, dimana nilai diagonal merupakan nilai akar kuadrat AVE dan nilai dibawahnya merupakan nilai korelasi antar konstruk.

Tabel 8. Nilai Kuadrat AVE

\begin{tabular}{|c|c|c|c|c|c|c|c|c|}
\hline Variabel & $\begin{array}{c}\text { Ekspals- } \\
\text { tasi } \\
\text { Kineja }\end{array}$ & $\begin{array}{c}\text { Ekspal:- } \\
\text { tasi } \\
\text { Usaha }\end{array}$ & $\begin{array}{l}\text { Kepuasan } \\
\text { Pengguna }\end{array}$ & $\begin{array}{c}\text { Kondisi } \\
\text { Yang } \\
\text { Memfasili } \\
\text { tasi }\end{array}$ & $\begin{array}{l}\text { Kualitas } \\
\text { Informasi }\end{array}$ & $\begin{array}{l}\text { Kualita } \\
\text { Sistem }\end{array}$ & $\begin{array}{l}\text { Pengarih } \\
\text { Sosial }\end{array}$ & $\begin{array}{l}\text { Siksp } \\
\text { Pada } \\
\text { Pengguns } \\
\text { an }\end{array}$ \\
\hline $\begin{array}{l}\text { Ekspeltasi } \\
\text { Kinerja }\end{array}$ & 0.876 & & & & & & & \\
\hline $\begin{array}{l}\text { Ekspeltasi } \\
\text { Usaha }\end{array}$ & 0.663 & 0.862 & & & & & & \\
\hline $\begin{array}{l}\text { Kepuasan } \\
\text { Pengguna }\end{array}$ & 0.667 & 0.629 & 0.927 & & & & & \\
\hline $\begin{array}{l}\text { Kondisi } \\
\text { Yang } \\
\text { Memfasilitasi }\end{array}$ & 0.609 & 0.524 & 0.701 & 0.794 & & & & \\
\hline $\begin{array}{l}\text { Kualitas } \\
\text { Informasi }\end{array}$ & 0.623 & 0.625 & 0.775 & 0.681 & 0.824 & & & \\
\hline $\begin{array}{l}\text { Kualitas } \\
\text { Sistem }\end{array}$ & 0.640 & 0.610 & 0.808 & 0.702 & 0.784 & 0.847 & & \\
\hline $\begin{array}{l}\text { Penganuh } \\
\text { Sosial }\end{array}$ & 0.668 & 0.598 & 0.675 & 0.627 & 0.662 & 0.646 & 0.800 & \\
\hline $\begin{array}{l}\text { Sikap Pada } \\
\text { Pengguansen }\end{array}$ & 0.681 & 0.575 & 0.739 & 0.689 & 0.687 & 0.668 & 0.732 & 0.932 \\
\hline
\end{tabular}

Sumber : Output SmartPLS 3.2.3.

Pada Tabel 8 terlihat bahwa nilai akar kuadrat AVE semua variabel lebih tinggi dibandingkan nilai korelasi, sehingga memenuhi persyaratan validitas diskriminan.

3) Uji Reliabilitas

Uji reliabilitas dilakukan untuk membuktikan akurasi, konsistensi dan ketepatan instrumen dalam mengukur konstruk. Untuk mengukur reliabilitas suatu konstruk dengan indikator reflektif dapat dilakukan dengan dua cara, yaitu dengan cronbach's alpha dan composite reliability yang sering disebut Dillon-Goldstein's. Namun demikian, penggunaan cronbach's alpha untuk menguji reliabilitas konstruk akan memberikan nilai yang lebih rendah (under estimate) sehingga lebih disarankan untuk menggunakan composite reliability (Ghozali dan Latan, 2015). Reliabilitas dikatakan baik apabila nilai cronbach's alpha dan composite reliability lebih besar dari 0.70. Namun dalam penelitian eksploratoris, $0.60-0.70$ masih dapat diterima (Sholihin dan Ratmono, 2013; Ghozali, 2014). Nilai composite reliability dan cronbach's alpha tersaji pada Tabel 9. 
Tabel 9. Nilai Composite Reliability dan Cronbach's Alpha

\begin{tabular}{|l|cc|}
\hline \multicolumn{1}{|c|}{ Variabel } & Cronbach's Alphe & Composite Reliability \\
\hline Ekspektasi Kimerja & 0.898 & 0.930 \\
\hline Ekspektasi Usaha & 0.885 & 0.920 \\
\hline Pengaruh Sosial & 0.813 & 0.877 \\
\hline Kondisi Yang Memfasilitasi & 0.805 & 0.872 \\
\hline Kualitas Informasi & 0.880 & 0.913 \\
\hline Kualitas Sistem & 0.869 & 0.910 \\
\hline Sikap Pada Penggumaan & 0.949 & 0.964 \\
\hline Kepuasan Pengguma & 0.918 & 0.948 \\
\hline
\end{tabular}

Sumber : Output SmartPLS 3.2.3.

Pada Tabel 9 terlihat bahwa nilai cronbach's alpha dan composite reliability pada semua variabel memiliki nilai $>0.70$. Dengan demikian dapat disimpulkan bahwa semua indikator variabel adalah reliabel atau memenuhi uji reliabilitas.

\subsubsection{Pengujian Model Struktural}

Pengujian model struktural dilakukan untuk melihat hubungan antara variabel, nilai signifikansi, dan $R$-Square atau Adjusted $\mathrm{R}^{2}$ dari model penelitian. Model struktural dievaluasi dengan menggunakan $R$-Square untuk konstruk dependen, Stone-Geisser $\mathrm{Q}^{2}$ test untuk predictive relevance dan uji $t$, serta signifikansi dari koefisien parameter jalur struktural (Ghozali, 2014). Penelitian ini menggunakan nilai Adjusted $\mathrm{R}^{2}$ karena penggunaan nilai R-Square akan menyebabkan bias estimasi. Hal ini disebabkan apabila predictor variabel dalam model semakin banyak, maka nilai $R$-Square akan semakin besar dan terus meningkat. Oleh karena itu dianjurkan menggunakan ukuran Adjusted $\mathrm{R}^{2}$ (Cohen, et al. dalam Ghozali 2014). Nilai Adjusted $\mathrm{R}^{2}$ untuk masing-masing variabel endogen tersaji pada Tabel 10.

Tabel 10. Nilai Adjusted $\mathbf{R}^{2}$

\begin{tabular}{|l|c|}
\hline \multicolumn{1}{|c|}{ Variabel Endogen } & Adjusted $\mathrm{R}^{2}$ \\
\hline Sikap Pada Penggunaan & 0.654 \\
\hline Kepuasan Pengguna & 0.543 \\
\hline
\end{tabular}

Sumber: Output SmartPLS 3.2.3.

Tabel 10 memperlihatkan nilai Adjusted $\mathrm{R}^{2}$ variabel sikap pada penggunaan sebesar 0.654 dan kepuasan pengguna sebesar 0.543. Semakin tinggi nilai Adjusted $\mathrm{R}^{2}$, maka semakin besar kemampuan variabel independen dapat dijelaskan oleh variabel dependen sehingga semakin baik persamaan struktural. Untuk variabel sikap pada penggunaan memiliki nilai Adjusted $\mathrm{R}^{2}$ sebesar 0.654 yang berarti $65,4 \%$ variance eskpektasi kinerja, ekspektasi usaha, pengaruh sosial, kondisi yang memfasilitasi, kualitas informasi dan kualitas sistem mampu dijelaskan oleh variabel sikap pada penggunaan, sedangkan sisanya dijelaskan oleh variabel lain di luar model penelitian. Variabel kepuasan pengguna memiliki nilai Adjusted $\mathrm{R}^{2}$ sebesar 0.543 yang berarti $54,3 \%$ variance ekspektasi kinerja, ekspektasi usaha, pengaruh sosial, kondisi yang memfasilitasi, kualitas informasi, kualitas sistem dan sikap pada penggunaan mampu dijelaskan oleh variabel kepuasan pengguna, sedangkan sisanya dijelaskan oleh variabel lain di luar model penelitian. Nilai Adjusted $\mathrm{R}^{2}$ untuk variabel sikap pada penggunaan sebesar 0.654 dan kepuasan pengguna sebesar 0.543 termasuk dalam kategori moderat.

Sedangkan untuk nilai Stone-Geiser $\mathrm{Q}^{2}$ diperoleh melalui prosedur blindfolding adalah prosedur pada PLS yang dikembangkan oleh Stone dan Geiser yang digunakan untuk menghitung Q2 (Ghozali, 2014). Nilai Stone-Geiser $\mathrm{Q}^{2}$ untuk variabel endogen sebagaimana tersaji pada Tabel 11.

Tabel 11. Nilai Stone-Geiser $\mathrm{Q}^{2}$

\begin{tabular}{|l|ccc|}
\hline \multicolumn{1}{|c|}{ VARIABEL } & SSO & SSE & $Q^{2}$ (=1-SSESSO) \\
\hline EkspektasiKinerja & 628.000 & 628.000 & \\
\hline EkspektasiUsaha & 628.000 & 628.000 & \\
\hline Kepuasan Pengguna & 471.000 & 251.320 & 0.466 \\
\hline Kondisi Yang Memfasilitasi & 628.000 & 628.000 & \\
\hline Kualitas Informasi & 785.000 & 785.000 & \\
\hline Kualitas Sistem & 628.000 & 628.000 & \\
\hline Pengaruh Sosial & 628.000 & 628.000 & \\
\hline Sikap Pada Pengguanaan & 628.000 & 271.994 & 0.567 \\
\hline
\end{tabular}

Sumber : Output SmartPLS 3.2.3.

Pada Tabel 11 menunjukkan bahwa nilai $\mathrm{Q}^{2}$ untuk variabel endogen kepuasan pengguna sebesar 0.466 dan sikap pada penggunaan sebesar 0.567. Nilai $\mathrm{Q}^{2}$ tersebut lebih besar dari nol $\left(Q^{2}>0\right)$ dan hal ini berarti bahwa model mempunyai relevansi prediktif.

\subsection{Pengujian Hipotesis}

Dasar untuk melihat signifikansi hubungan antara variabel laten eksogen dan endogen dalam hipotesis ini adalah dengan melihat besaran nilai $t$-statistic dan $p$-value. Tingkat signifikansi yang digunakan dalam penelitian ini adalah $5 \%$. Nilai tstatistics $>1.96$ dan $p$-value $<0.05$ dikatakan signifikan pada alpha $5 \%$. Hal ini berarti bahwa hipotesis bisa diterima. Nilai t-statistics dan $p$ value terlihat pada Tabel 12 . 


\section{Tabel 12. Hasil Pengujian Hipotesis}

\begin{tabular}{|c|c|c|c|c|c|c|}
\hline & $\begin{array}{l}\text { Original } \\
\text { Sample } \\
(0)\end{array}$ & $\begin{array}{c}\text { Sample } \\
\text { Mean } \\
\text { (M) }\end{array}$ & $\begin{array}{l}\text { Standard } \\
\text { Deriation } \\
\text { (STDEV) }\end{array}$ & $\begin{array}{l}\text { tstatistics } \\
(\mid 0 / \text { STDEV })\end{array}$ & $\begin{array}{c}\mathrm{p} \\
\text { values }\end{array}$ & $\begin{array}{c}\text { Hasil } \\
\text { Pengujian }\end{array}$ \\
\hline $\begin{array}{l}\text { Ekspektasi Kinerja } \gg \text { Sikap Pada } \\
\text { Penggunaan }\end{array}$ & 0.196 & 0.206 & 0.117 & 1.678 & 0.094 & Ditolak \\
\hline $\begin{array}{l}\text { Ekspektasi Usaha \Sikap Pada } \\
\text { Penggunaan }\end{array}$ & 0.008 & 0.001 & 0.079 & 0.097 & 0.923 & Ditolak \\
\hline $\begin{array}{l}\text { Penganuh Sosial }>\text { Sikap Pada } \\
\text { Penggunaan }\end{array}$ & 0.319 & 0.324 & 0.076 & 4.173 & 0.000 & Diterima \\
\hline $\begin{array}{l}\text { Kondisi YangMemfasilitasi } \text { - } \\
\text { Sikap Pada Penggunaan }\end{array}$ & 0.222 & 0.215 & 0.092 & 2.427 & 0.016 & Ditenma \\
\hline $\begin{array}{l}\text { Kualitas Infomasi }>\text { Sikap Pada } \\
\text { Penggunaan }\end{array}$ & 0.154 & 0.135 & 0.133 & 1.158 & 0.247 & Ditolak \\
\hline $\begin{array}{l}\text { Kualitas Sistem } \gg \text { Sikap Pada } \\
\text { Penggunaan }\end{array}$ & 0.055 & 0.073 & 0.114 & 0.482 & 0.630 & Ditolak \\
\hline $\begin{array}{l}\text { Sikap Pada Penggunaan > } \\
\text { Kepuasan Pengguma }\end{array}$ & 0.739 & 0.738 & 0.048 & 15.343 & 0.000 & Diterima \\
\hline
\end{tabular}

Sumber: Output SmartPLS 3.2.3.

\subsection{Hasil Penelitian}

Pengujian ditunjukkan melalui hipotesis yang ada sehingga dapat diketahui bagaimana pengaruh masing-masing variabel terhadap variabel lainnya. Ringkasan hasil pengujian terangkum dalam Tabel 13. Pada tabel tersebut terlihat bahwa dari 7 hipotesis dalam penelitian ini, terdapat 3 hipotesis yang diterima yaitu $\mathrm{H} 3$, $\mathrm{H} 4$ dan $\mathrm{H} 7$, sedangkan yang ditolak yaitu $\mathrm{H} 1, \mathrm{H} 2$, H5 dan H6.

\section{Tabel 13. Ringkasan Hasil Pengujian}

\begin{tabular}{|c|c|c|c|c|c|}
\hline & Hipotesis & $\begin{array}{l}\text { Original } \\
\text { Sample } \\
\text { (0) }\end{array}$ & $\begin{array}{l}\text { Sample } \\
\text { Mean } \\
\text { (M) }\end{array}$ & $\begin{array}{l}t \text { statistics } \\
(\mid 0 / \text { STDEV })\end{array}$ & $\begin{array}{c}\text { Hasil } \\
\text { Pengujian }\end{array}$ \\
\hline $\mathrm{Hl}$ & $\begin{array}{l}\text { Ekspektasi kinerja berpengaruh } \\
\text { positif terhadap sikap pada } \\
\text { penggunaan }\end{array}$ & 0.196 & 0.206 & 1.678 & Ditolak \\
\hline $\mathrm{H} 2$ & $\begin{array}{l}\text { Ekspektasi us aha berpengaruh } \\
\text { positif terhadap sikap pada } \\
\text { penggunaan }\end{array}$ & 0.008 & 0.001 & 0.097 & Ditolak \\
\hline $\mathrm{H} 3$ & $\begin{array}{l}\text { Pengaruh so sial berpengaruh positif } \\
\text { terhadap sikanpada pangannan }\end{array}$ & 0.319 & 0.324 & 4.173 & Diterima \\
\hline $\mathrm{H} 4$ & $\begin{array}{l}\text { Kondisi yang memfasilitasi } \\
\text { berpengaruhpositif terhadap sikap } \\
\text { pada penggunagn }\end{array}$ & 0.222 & 0.215 & 2.427 & Diterima \\
\hline H5 & $\begin{array}{l}\text { Kualitas informasi berpengaruh } \\
\text { positif terhadap sikap pada } \\
\text { penggunaan }\end{array}$ & 0.154 & 0.135 & 1.158 & Ditolak \\
\hline $\mathrm{H} 6$ & $\begin{array}{l}\text { Kualitas sistem berpengaruhp ositif } \\
\text { terhadap sikap pada penggunan }\end{array}$ & 0.055 & 0.073 & 0.482 & Ditolak \\
\hline $\mathrm{H} 7$ & $\begin{array}{l}\text { Sikap pada penggunaan } \\
\text { berpengaruhpositif terhadap } \\
\text { kepuas an pengguna }\end{array}$ & 0.739 & 0.738 & 15.343 & Diterima \\
\hline
\end{tabular}

Sumber: Output SmartPLS 3.2.3.

\subsection{Pembahasan}

\subsubsection{Pengaruh Ekspektasi Kinerja Terhadap Sikap Pada Penggunaan (H1)}

Pengaruh tidak signifikannya hubungan antara ekspektasi kinerja dengan sikap pada penggunaan menunjukkan bahwa ekspektasi terhadap kinerja sistem yang diharapkan licenced user kurang memiliki peranan penting dalam menentukan sikap mereka untuk menggunakan SPAN. Statistik deskriptif dari variabel ini menunjukkan nilai kisaran dan rata-rata aktual lebih tinggi dibanding nilai kisaran dan rata-rata teoritis. Nilai kisaran teoritisnya sebesar 4 s.d 20 dengan nilai rata-rata 12.00 , sedangkan nilai kisaran aktual adalah 8 s.d. 20 dengan nilai ratarata sebesar 16.84. Dengan demikian dapat disimpulkan bahwa responden percaya dengan menggunakan SPAN dapat membantu meningkatkan kinerja. Akan tetapi, ekspektasi kinerja tersebut ternyata bukanlah faktor yang mempengaruhi baik tidaknya sikap licenced user dalam menggunakan SPAN.

Hasil penelitian ini tidak sejalan dengan pendekatan teori TAM yang menyatakan bahwa perilaku menggunakan TI diawali oleh adanya persepsi mengenai kegunaan dan persepsi mengenai kemudahan menggunakan IT. Persepsi terhadap manfaat TI dan persepsi terhadap kemudahan penggunaan TI mempengaruhi sikap individu terhadap penggunaan TI.

Hasil penelitian ini tidak sejalan dengan penelitian Thomas (2008) yang dalam penelitiannya menyatakan bahwa ekspektasi kinerjasecara signifikan positif terkait dengan sikap terhadap penggunaan. Begitu juga dengan hasil penelitian Koh, et al. (2010) yang menyatakan bahwa ekspektasi kinerja pada sistem berpengaruh positif terhadap sikap dalam menggunakan sistem tersebut. Hasil penelitian ini juga tidak sejalan dengan penelitian Hendrawati (2013) yang menyatakan bahwa mental penerimaan dipengaruhi secara langsung oleh ekspektasi kinerja.

\subsubsection{Pengaruh Ekspektasi Usaha Terhadap Sikap Pada Penggunaan (H2)}

Pengaruh tidak signifikannya hubungan antara ekspektasi usaha dan sikap pada penggunaan menunjukkan bahwa ekspektasi usaha yang diharapkan licenced user kurang memiliki peranan penting dalam menentukan sikap mereka untuk menggunakan SPAN. Statistik deskriptif dari variabel ini menunjukkan nilai kisaran dan rata-rata aktual lebih tinggi dibanding nilai kisaran dan rata-rata teoritis. Nilai kisaran teoritisnya adalah 4 s.d 20 dengan nilai rata-rata 12.00 , sedangkan nilai kisaran aktual 
adalah 10 s.d. 20 dengan nilai rata-rata sebesar 16.52. Hal ini berarti responden percaya bahwa menggunakan SPAN itu mudah, namun ekspektasi usaha tersebut ternyata bukanlah faktor yang mempengaruhi baik tidaknya sikap licenced user dalam menggunakan SPAN.

Hasil penelitian ini tidak sejalan dengan pendekatan teori TAM yang menyatakan bahwa persepsi terhadap manfaat TI juga mempengaruhi persepsi kemudahan penggunaan TI tetapi tidak berlaku sebaliknya. Dengan demikian, selama individu merasa bahwa TI bermanfaat dalam tugas-tugasnya, ia akan berniat untuk menggunakannya terlepas apakah TI itu mudah atau tidak untuk digunakan. Pengguna teknologi informasi mempercayai bahwa teknologi informasi yang lebih fleksibel, mudah dipahami dan mudah dalam hal pengoperasiannya akan menimbulkan sikap yang baik dalam penggunaan teknologi informasi tersebut.

SPAN merupakan bagian dari sistem informasi manajemen keuangan terintegrasi yang sangat berbeda dengan sebelumnya dan mempunyai kompleksitas yang sangat tinggi. Dan jika dilihat dari komposisi responden dengan usia yang sebagian besar sudah tidak muda lagi (59,2\% berusia 46-55 tahun), maka tidak mudah bagi mereka untuk cepat dan terampil menggunakan SPAN. Selain itu, jumlah responden yang tidak pernah mengikuti pelatihan terkait SPAN juga cukup signifikan, yaitu sebesar 22,3\%. Hal ini dapat mempengaruhi tingkat kemudahan yang diharapkan oleh responden dalam menggunakan SPAN.

Hasil penelitian ini sejalan dengan penelitian Widodo (2012) yang menyatakan bahwa sikap terhadap penggunaan SPAN dipengaruhi secara positif oleh persepsi kemudahan penggunaan dan persepsi kegunaan. Namun, penelitian ini tidak sejalan dengan penelitian Thomas (2008) yang menyatakan bahwa ekspektasi usaha berpengaruh positif terhadap sikap pada penggunaan. Hasil penelitian ini juga tidak sejalan dengan penelitian Hendrawati (2013) yang menyatakan bahwa mental penerimaan dipengaruhi secara langsung oleh ekspektasi usaha.

\subsubsection{Pengaruh Faktor Pengaruh Sosial Terhadap Sikap Pada Penggunaan (H3)}

Pengaruh signifikannya hubungan antara pengaruh sosial dan sikap pada penggunaan menunjukkan bahwa pengaruh orang lain atau lingkungan sekitar memiliki peranan penting dalam menentukan sikap dalam menggunakan SPAN. Statistik deskriptif variabel ini menunjukkan nilai kisaran dan rata-rata aktual lebih tinggi dibanding nilai kisaran dan rata-rata teoritis. Nilai kisaran teoritis untuk variabel ini adalah 4 s.d 20 dengan nilai rata-rata 12.00 , sedangkan nilai kisaran aktual adalah 9 s.d. 20 dengan nilai rata-rata sebesar 17.34. Dengan demikian dapat disimpulkan bahwa responden percaya apabila pengaruh sosial sangat kuat mempengaruhi sikapnya dalam menggunakan SPAN.

Hasil penelitian ini sejalan dengan pendekatan teori UTAUT yang menyatakan bahwa seorang individu menganggap orang lain dapat menyakinkan dirinya bahwa dia harus menggunakan sistem baru. Hasil penelitian juga sejalan dengan penelitian yang dilakukan oleh Koh, et al. (2010) yang menyatakan bahwa kinerja seorang pengguna menggunakan sistem dipengaruhi oleh kinerja pengguna lain. Dengan demikian, bila pengguna membentuk sikap terhadap sistem, hal itu pasti dipengaruhi olehatasan dan rekan kerja tentang konsekuensi atas penggunaan sistem tersebut. Pengaruh sosial secara signifikan mempengaruhi sikap perilaku pengguna. Namun, penelitian ini tidak sejalan dengan penelitian Hendrawati (2013) yang menyatakan bahwa pengaruh sosial tidak memiliki pengaruh secara signifikan terhadap mental penerimaan.

\subsubsection{Pengaruh Kondisi Yang Memfasilitasi Terhadap Sikap Pada Penggunaan (H4)}

Pengaruh signifikannya hubungan antara kondisi yang memfasilitasi dan sikap pada penggunaan menunjukkan bahwa ketersediaan fasilitas memiliki peranan penting dalam menentukan sikap responden untuk menggunakan SPAN. Statistik deskriptif variabel ini menunjukkan nilai kisaran dan rata-rata aktual lebih tinggi dibanding nilai kisaran dan rata-rata teoritis. Nilai kisaran teoritis untuk variabel ini adalah 4 s.d 20 dengan nilai rata-rata 12.00 , sedangkan nilai kisaran aktual adalah 8 s.d. 20 dengan nilai rata-rata sebesar 15.92 . Kesimpulan yang dapat ditarik di sini adalah responden percaya bahwa baiknya kondisi yang memfasilitasi mempengaruhi sikapnya dalam menggunakan SPAN.

Hasil penelitian ini sejalan dengan pendekatan teori UTAUT yang menyatakan bahwaseorang individu percaya jika infrastruktur organisasi dan teknis yang ada dapat mendukung penggunaan sistem. Namun uji hipotesis ini tidak sejalan dengan penelitian Thompson, et al. (1991) yang mengadopsi sebagian teori yang diusulkan oleh Triandis (1980). Penelitian tersebut menemukan bahwa tidak ada hubungan antara kondisi yang memfasilitasi pemakai dengan penggunaan teknologi informasi. Dalam konsep ini terdapat gabungan variabel-variabel yang diperoleh dari model penelitian sebelumnya 
tentang model penerimaan dan penggunaan teknologi. Variabel tersebut adalah kontrol perilaku persepsian, dan kondisi-kondisi yang memfasilitasi, serta kompatibilitas. Hasil penelitian ini tidak sejalan juga dengan penelitian Hendrawati (2013) yang menyatakan bahwa kondisi yang memfasilitasi tidak memiliki pengaruh secara signifikan terhadap mental penerimaan. Begitu juga dengan penelitian Teo (2012) yang menyatakan bahwa kondisi yang memfasilitasi tidak mempengaruhi secara signifikan terhadap sikap pada penggunaan.

\subsubsection{Pengaruh Kualitas Informasi Terhadap Sikap Pada Penggunaan (H5)}

Pengaruh tidak signifikannya hubungan antara kualitas informasi dan sikap pada penggunaan menunjukkan bahwa kualitas sistem yang diharapkan kurang memiliki peranan penting dalam menentukan sikap mereka untuk menggunakan SPAN. Statistik deskriptif dari variabel ini menunjukkan nilai kisaran dan ratarata aktual lebih tinggi dibanding nilai kisaran dan rata-rata teoritis. Nilai kisaran teoritis untuk variabel ini adalah 5 s.d 25 dengan nilai rata-rata 15.00, sedangkan nilai kisaran aktual adalah 10 s.d. 25 dengan nilai rata-rata sebesar 20.91 . Dengan demikian dapat disimpulkan bahwa responden percaya SPAN mampu menghasilkan informasi dengan kualitas tinggi, namun kualitas informasi tersebut ternyata bukanlah faktor yang mempengaruhi baik tidaknya sikap licenced user dalam menggunakan SPAN.

Hasil penelitian ini tidak sejalan dengan Wixom dan Todd (2005) yang menyatakan bahwa dalam hal kualitas informasi, kepercayaan berbasis obyek ini adalah persepsi pengguna terhadap kualitas informasi yang disertakan dalam sistem. Apabila segala sesuatu yang lain tetap konstan, pengguna akan puas dengan sedikit informasi jika mempunyai kualitas yang baik. Hal ini meningkatkan kepercayaan pengguna dalam menggunakan informasi untuk melaksanakan tugas-tugasnya. Dengan kata lain, pengguna puas dengan kualitas informasi yang dia terima dari sistem ini akan lebih mungkin untuk memahami bahwa informasi akan meningkatkan kinerjanya. Hasil penelitian ini juga tidak sejalan dengan penelitian Hendrawati (2013) yang menyatakan bahwa mental penerimaan pegawai dipengaruhi oleh kualitas informasi yang dapat mempengaruhi tingkat kepuasan pegawai terhadap perolehan informasi.

\subsubsection{Pengaruh Kualitas Sistem Terhadap Sikap Pada Penggunaan (H6)}

Pengaruh tidak signifikannya hubungan antara kualitas sistem dan sikap pada penggunaan menunjukkan bahwa kualitas sistem yang diharapkan dari SPAN kurang memiliki peranan penting dalam menentukan sikap mereka untuk menggunakan SPAN. Statistik deskriptif dari variabel ini menunjukkan nilai kisaran dan rata-rata aktual lebih tinggi dibanding nilai kisaran dan rata-rata teoritis. Nilai kisaran teoritis untuk variabel ini adalah 4 s.d 20 dengan nilai rata-rata 12.00 , sedangkan nilai kisaran aktual adalah 11 s.d 20 dengan nilai ratarata sebesar 16.71. Berdasarkan hasil tersebut, dapat disimpulkan bahwa responden percaya SPAN merupakan sistem yang memiliki kualitas kinerja tinggi, namun kualitas sistem tersebut ternyata bukanlah faktor yang mempengaruhi baik tidaknya sikap licenced user dalam menggunakan SPAN.

Hasil penelitian ini tidak sejalan dengan DeLone dan McLean (1992) yang menyatakan bahwa kualitas sistem memiliki efek langsung pada penggunaan dan kepuasan pengguna. Selain itu, hasil penelitian ini berbeda dengan pendapat Nelson, et al. (2005) yang mengandaikan bahwa meskipun kemudahan penggunaan dan kualitas sistem serupa, kemudahan penggunaan mungkin merupakan anteseden kualitas sistem.

\subsubsection{Pengaruh Sikap Pada Penggunaan Terhadap Kepuasan Pengguna (H7)}

Pengaruh signifikannya hubungan antara sikap pada penggunaan terhadap kepuasan pengguna menunjukkan bahwa respon positif memiliki peranan penting dalam menentukan kepuasan responden untuk menggunakan SPAN. Statistik deskriptif variabel sikap pada penggunaan menunjukkan nilai kisaran dan ratarata aktual lebih tinggi dibanding nilai kisaran dan rata-rata teoritis. Nilai kisaran teoritis untuk variabel ini adalah 4 s.d 20 dengan nilai rata-rata 12.00, sedangkan nilai kisaran aktual adalah 9 s.d 20 dengan nilai rata-rata sebesar 17.13 . Sedangkan statistik deskriptif variabel kepuasan pengguna juga menunjukkan nilai kisaran dan rata-rata aktual lebih tinggi dibanding nilai kisaran dan rata-rata teoritis. Nilai kisaran teoritis untuk variabel ini adalah 3 s.d 15 dengan nilai rata-rata 9.00, sedangkan nilai kisaran aktual adalah 6 s.d 15 dengan nilai rata-ratanya sebesar 12.42.Dengan demikian dapat disimpulkan bahwa responden percaya jika SPAN mampu memenuhi harapan mereka sehingga memberikan kepuasan yang tinggi dalam menggunakan SPAN. 
Hasil penelitian ini sejalan dengan DeLone dan McLean (1992) yang menyatakan bahwa sikap pengguna terhadap penggunaan sistem dikaitkan dengan kepuasan pengguna. Sikap dapat menjadi predisposisi untuk merespon positif atau tidak untuk stimulus dalam sistem (Ajzen, 1991). Sikap positif lebih cenderung mengarah pada perasaan kepuasan dengan sistem.

Hasil penelitian ini sejalan dengan penelitian-penelitian sebelumnya. Studi empiris menunjukkan dukungan yang konsisten dan positif terhadap hubungan yang signifikan antara sikap dan kepuasan pengguna (misalnya, Koh, et al. 2010; Igbaria dan Nachman, 1990). Dalam penelitiannya Teo juga menemukan bahwa kompleksitas teknologi memiliki pengaruh langsung dan signifikan terhadap sikap penggunaan teknologi. ${ }^{19}$ Kepuasan pengguna adalah salah satu komponen kunci dari keberhasilan sistem.

\section{KESIMPULAN DAN SARAN}

\subsection{Kesimpulan}

Penelitian ini dilakukan berdasarkan kerangka penelitian yang dijadikan dasar pengujian mengenai faktor-faktor yang mempengaruhi sikap dan kepuasan licenced user SPAN, yang meliputi faktor ekspektasi kinerja, ekspektasi usaha, pengaruh sosial, kondisi yang memfasilitasi, kualitas informasi dan kualitas sistem. Penelitian dijabarkan dalam 7 hipotesis dan pengujian dilakukan dengan menggunakan perangkat SmartPLS 3.2.3.

Populasi dalam penelitian ini adalah licenced user SPAN pada KPPN seluruh Indonesia dengan sampel licenced user pada KPPN lingkup Jawa Tengah (15 KPPN). Pengambilan sampel menggunakan metode area sampling dengan jumlah sampel sebanyak 160 responden. Kuesioner dikirim secara serentak pada tanggal 26 Oktober 2015. Tingkat pengembalian kuesioner sampai batas waktu yang ditentukan sebanyak 157 responden (98,13\%). Data kemudian dianalisis yang menghasilkan rata-rata aktual jawaban responden pada semua variabel diatas rata-rata teoritisnya. Hal ini menunjukkan bahwa persepsi responden atas semua variabel cenderung baik.

19 T. Teo, "Modelling the Influences of Beliefs on Pre-Service Teachers' Attitudes towards Computer Use", European Journal of Educational Research, 2012, Vol. 1, No.1.
Hasil uji non-response bias terhadap data yang diolah telah memenuhi syarat representasi populasi. Pengujian model pengukuran juga telah memenuhi syarat validitas (konvergen dan diskriminan) dan reliabilitas. Untuk pengujian model struktural, nilai adjusted $\mathrm{R}^{2}$ variabel endogen sikap pada penggunaan sebesar 0.654 dan kepuasan pengguna sebesar 0.543 yang berarti termasuk dalam kategori moderat. Nilai Stone-Geiser $\mathrm{Q}^{2}$ kedua variabel endogen masingmasing sebesar 0.466 dan 0.567 yang menunjukkan bahwa model mempunyai relevansi prediktif.

Dari pengujian hipotesis diketahui bahwa dari 7 hipotesis yang diajukan, sebanyak 3 hipotesis diterima (H3, H4 dan H7) dan 4 hipotesis ditolak (H1, H2, H5 dan H6). Dan dari hasil pengujian hipotesis dapat disimpulkan bahwa pengaruh sosial dan kondisi yang memfasilitasi berpengaruh positif dan signifikan terhadap sikap pada penggunaan SPAN. Demikian juga untuk variabel sikap pada penggunaan yang memberikan pengaruh positif dan signifikan terhadap kepuasan pengguna. Sedangkan variabel yang lain, yaitu ekspektasi kinerja, ekspektasi usaha, kualitas informasi dan kualitas sistem tidak berpengaruh terhadap sikap pada penggunaan SPAN.

\subsection{Saran}

Hasil penelitian ini masih jauh dari sempurna dengan banyak keterbatasan. Namun demikian hasil penelitian ini dapat dijadikan inspirasi dan masukan untuk pengembangan penelitian-penelitian berikutnya. Saran yang dapat direkomendasikan untuk peneliti berikutnya adalah:

1) Obyek penelitian berikutnya agar dilakukan untuk seluruh licenced user SPAN, sehingga hasil penelitian dapat digeneralisasi;

2) Pengujian terhadap populasi yang lebih beragam dapat dilakukan untuk memperkaya kajian tentang sikap dan kepuasan pengguna SPAN, seperti pengguna eksternal SPAN (stakeholder);

3) Penelitian berikutnya agar memasukkan faktor-faktor lain yang mempengaruhi sikap dan kepuasan pengguna SPAN seperti kualitas layanan dan kinerja;

4) Metode pengumpulan data tidak hanya dengan kuesioner tapi ditambah melalui wawancara sehingga terdapat kesamaan persepsi atas suatu indikator;

5) Penelitian selanjutnya dapat dilakukan dengan pendekatan beberapa periode waktu (longitudinal survey) sehingga analisis yang 
dihasilkan akan lebih lengkap dan mendapatkan data statistik yang lebih obyektif.

\section{IMPLIKASI DAN KETERBATASAN}

\subsection{Implikasi}

\subsubsection{Implikasi Teoritis}

Penelitian ini diharapkan dapat menambah khasanah keilmuan dalam bidang akuntansi keperilakuan untuk kesuksesan sistem informasi dengan menggunakan model integrasi. Melalui penelitian ini diperoleh bukti empiris bahwa persepsi kemudahan penggunaan dan kemanfaatan tidak berpengaruh terhadap sikap dalam menggunakan sistem. Hal ini tidak sejalan dengan pendekatan teori TAM yang menekankan pada persepsi kemudahan penggunaan dan kemanfaatan yang memiliki hubungan untuk memprediksi sikap dalam menggunakan sistem informasi. Hasil penelitian ini memberikan referensi bahwa kepuasan pengguna dipengaruhi secara signifikan oleh sikap pengguna dalam menggunakan sistem informasi, terutama di lingkungan pengaturan wajib. Dalam pendekatan dengan teori TAM, tidak menyatakan adanya hubungan antara sikap dan kepuasan pengguna, dan tidak membedakan lingkungan pengaturan (sukarela atau wajib).

\subsubsection{Implikasi Praktis}

Terkait implikasi praktis dalam implementasi SPAN, diketahui bahwa sikap licenced user SPAN dalam menggunakan SPAN tidak dipengaruhi oleh ekspektasi kinerja, ekspektasi usaha, kualitas sistem dan kualitas informasi. Hasil penelitian ini dapat digunakan sebagai usulan bagi pengembang sistem maupun pengambil keputusan.

Bagi teknisi/ pengembang sistem, hasil penelitian dapat dijadikan masukan untuk pengembangan sistem dan tolok ukur dalam evaluasi sistem. Selain itu perlu diperhatikan juga tingkat kemudahan dan kenyamaan dalam menggunakan SPAN sehingga menjadi sistem yang lebih mudah digunakan (user friendly) dan nyaman. Selanjutnya, perlu diperhatikan kualitas informasi yang dihasilkan sistem yaitu tingkat keakuratan, kelengkapan, format yang baik, tingkat relevansi dan adanya jaminan tingkat kemanan informasi karena kualitas informasi merupakan salah satu faktor yang sangat mempengaruhi dalam menggunakan SPAN.

Bagi DJPBN, hasil penilitian ini dapat dijadikan sebagai bahan evaluasi dalam penerapan SPAN sehingga menjadi sistem yang berkelanjutan. Selain itu, hasil penelitian ini dapat digunakan sebagai bahan pertimbangan dalam merencanakan pengembangan sumber daya yang berkompeten dalam menunjang operasional sistem untuk memberikan dampak positif baik bagi licenced user maupun organisasi. Sumber daya yang dimaksud adalah fasilitas penunjang operasional maupun keahlian dan pengetahuan licenced user dalam penggunaan sistem. Menambah pelatihanpelatihan dalam menggunakan SPAN merupakan salah satu contoh yang dapat dilakukan untuk meningkatkan kemampuan licenced user.

\section{Keterbatasan}

Penelitian ini telah dilakukan sesuai dengan prosedur ilmiah, namun demikian hasil analisis masih memiliki keterbatasan, yaitu:

1) Obyek penelitian ini adalah licenced user SPAN KPPN lingkup Jawa Tengah, sehingga mungkin belum dapat mewakili licenced user SPAN secara keseluruhan;

2) Penelitian ini hanya menguji populasi licenced user internal SPAN yang ada di KPPN. Sedangkan pengguna SPAN tidak hanya internal tapi juga eksternal, yang merasakan dampak dari pelaksanaan SPAN;

3) Variabel yang digunakan dalam penelitian ini masih sangat terbatas. Terdapat faktor-faktor lain yang dapat dipertimbangkan untuk melengkapi penelitian dan mempengaruhi hasil penelitian;

4) Instrumen penelitian yang digunakan adalah kuesioner yang telah diuji validitas dan reliabilitasnya. Namun demikian, hasil survei sangat tergantung kepada berbagai faktor yang dapat menyebabkan hasil yang bervariasi, sesuai persepsi individu yang bersifat subyektif;

5) Penelitian ini dilakukan hanya pada satu periode waktu yang tidak dapat mengungkapkan faktor-faktor yang memiliki dampak jangka panjang.

\section{PENGHARGAAN (ACKNOWLEDGEMENT)}

Penulis menyadari bahwa tanpa bantuan dan bimbingan dari berbagai pihak, dari masa perkuliahan sampai pada penyusunan jurnal ini, sangatlah sulit bagi penulis untuk menyelesaikan jurnal ini. Oleh karena itu, penulis mengucapkan terima kasih yang sebesar-besarnya kepada dosen dan pengelola Program Studi Magister Sains Akuntasni Fakultas Ekonomi dan Bisnis Universitas Diponegoro, dan semua pihak yang telah membantu dalam penyelesaian jurnal ini yang tidak dapat penulis sebutkan satu persatu. 


\section{DAFTAR PUSTAKA (REFERENCES)}

Adams D.A., Nelson R.R., and Todd P.A. (1992). "Perceived Usefulness, Ease of Use, and Usage of Information Technology: A Replication". MIS Quarterly, Vol. 16, No. 2, hlm. 227-247.

Ajzen, I., and Fishbein, M. (1980). Understanding Attitudes and Predicting Social Behaviour. Englewood Cliffs, NJ: PrenticeHall.

Bodnar, G. H dan Hopwood, W.S. (2006). Sistem Informasi Akuntansi. Edisi Bahasa Indonesia oleh Julianto Agung Saputra dan Lilis Setiawati, Edisi 9. Yogyakarta: Penerbit Andi.

Chin, W.C. and Todd, P.A. (1995). "On the Use, Usefulness and Ease of Use of Structural Equation Modelling in MIS Research: A Note of Caution". MIS Quarterly, Vol. 19, hlm. 237-246.

Davis, F.D. (1986). "Technology Acceptance Model for Empirically Testing New EndUser Information Systems Theory and Results". Unpublished Doctoral Dissertation, MIT.

Davis, F. D. (1989). "Perceived Usefulness, Perceived Ease of Use, and User Acceptance of Information Technology". MIS Quarterly, Vol. 13, No. 3, hlm. 319-339.

DeLone, W. H., and McLean E. R. (1992). "Information Systems Success: The Quest for the Dependent Variable". Information Systems Research, Vol.3, No. 1, hlm. 60-95.

DeLone, W. H., and McLean, E. R. (2003). "The DeLone and McLean Model of Information Systems Success: A Ten-Year Update". Journal of Management Information Systems, Vol.19, No. 4, hlm. 9-3.

Doll, W.J, and Torkzadeh, G. (1988). "The Measurement of End-User Computing Satisfaction". MISQuarterly, Vol.12.

Ghozali, I. (2011). Aplikasi Analisis Multivariate Dengan Program IBM SPSS 19. Edisi 5. Semarang: Badan Penerbit Undip.

Ghozali, I. (2011). Structural Equation Modeling Metode Alternatif Dengan Partial Least Square (PLS). Edisi 3. Semarang: Badan Penerbit Undip.

Ghozali, I. (2014). Partial Least Squares: Konsep, Metode dan Aplikasi Menggunakan WarpPLS 4.0. Edisi 2. Semarang: Badan Penerbit Undip.

Ghozali, I dan Latan, H. (2015). Partial Least
Squares: Konsep, Metode dan Aplikasi Menggunakan Program SmartPLS 3.2.1 Untuk Penelitian Empiris. Edisi 2. Semarang: Badan Penerbit Undip.

Hendrawati, T. (2013). Analisis Penerimaan Sistem Informasi Integreated Library System (INLIS). Visi Pustaka, Vol.15, No.3.

Igbaria, M and Nachman, S.A. (1990). "Correlates of User satisfaction With End User Computing: an Exploratory Study". Journal Information and Management, Vol. 19.

Kaban. A.L. (2009). "Business Process Analysis: Sistem Perbendaharaan dan Anggaran Negara (SPAN)".Ultima InfoSys, Vol.1, No.1.

Kimwele and Musee, J. (2011). "Factors affecting effective implementation of Intergrated Financial Management Information Systems (IFMIS) in government ministries in Kenya".

Koh, C.E, Prybutok, V.R, Ryan, S.D and Wu, Y.A. (2010). "A Model for Mandatory Use of Software Technologies: An Integrative Approach by Applying Multiple Levels of Abstraction of Informing Science". Informing Science: the International Journal of an Emerging Transdiscipline, Vol.13.

Mardiasmo, (2002). Akuntansi Sektor Publik. Yogyakarta: Penerbit ANDI.

Nelson, R., Todd, P. A., and Wixom, B. H. (2005). "Antecedents of Information and System Quality: An Empirical Examination within the Context of Data Warehosing". Journal of Management Information Systems, Vol. 21, No. 4, hlm. 199-235.

Putra, D.H. (2013). “Analisis Faktor-faktor Yang Mempengaruhi Sikap Terhadap Penerimaan dan Penggunaan Sistem Perbendaharaan dan Anggaran Negara (SPAN) Dengan Pendekatan Technology Acceptance Model". Jurnal Publikasi, University of Mercu Buana.

Rawstorne, P., Jayasuriya, R. and Caputi, P. (1998). "An integrative model of information systems use in mandatory environments". Paper disajikan pada Proceedings of the Nineteenth International Conference on Information Systems, Helsinki, Finland, 31 Desember 1998.

Sekaran, U and Bougie, R. (2010). Research Methods for Business: A Skill Building Approach. Fift Edition. United Kingdom: John Wiley \& Sons. 
Teo, T. (2012). "Modelling the Influences of Beliefs on Pre-Service Teachers' Attitudes towards Computer Use". European Journal of Educational Research, Vol. 1, No.1.

Thomas, P. 2008. "Information Systems Success and Technology Acceptance within a Government Organization." Dissertation, School of Buisness Computer Information System, University of North Texas.

Thompson, R. L. Higgins, C. A., and Howell, J. M., (1991). "Personal Computing: Toward a Conceptual Model of Utilization".MIS Quarterly, Vol. 15, No. 1, hlm. 124-143.

Triandis, H. C. (1980). "Values, Attitudes, and Interpersonal Behavior", in $\mathrm{H}$. Howe and. M. Page (Eds.), Nebraska Symposium on Motivation, Lincoln, NE: University of Nebraska Press., hlm. 195-2690

Venkatesh, V., Morris, M. G., Davis, G. B., and Davis, F. D. (2003). "User Acceptance of Information Technology: Toward a Unified View". MIS Quarterly, Vol. 27, No. 3, hlm. 425-447.

Widodo, K. (2012). "Analisis Studi Keberterimaan Inisial Sistem Perbendaharaan dan Anggaran Negara (SPAN) Studi Pada Kantor Pelayanan Perbendaharaan Negara". Tesis, Tidak Dipublikasikan, School of Management, University of Gadjah Mada.

Wixom, B. H., and Todd, P. A. (2005). "A Theoretical Integration of User Satisfaction and Technology Acceptance". Information Systems Research, Vol. 16, No. 1, hlm. 85-102. 